Danmarks Geologiske Undersøgelse.

III. Række. Nr. 24.

\title{
Jordbundskort over Danmark
}

\section{Soil Map of Denmark}

C. H. Bornebusch og Keld Milthers.

Dansk og engelsk Tekst.

Danish and English Text.

I Kommission hos

C. A. Reitzels Forlag

København

1935

Pris: $12 \mathrm{Kr}$. 
Danmarks Geologiske Undersøgelse.

III. Række. Nr. 24.

\title{
Jordbundsk ort over Danmark
}

Soil Map of Denmark

\author{
ved \\ C. H. Bornebusch og Keld Milthers. \\ Dansk og engelsk Tekst. \\ Danish and English Text.
}

I Kommission hos

C. A. Reitzels Forlag

København

1935 


\section{Indholdsfortegnelse.}

Contents.

Fortale (Victor Madsen) . Side

Danmarks Overfladelag (KeLD Milthers).......... 7

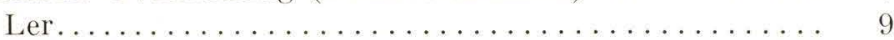

Diluvialsand .......................... 14

Hedesand......................... 17

Senglaciale marine Dannelser............... 20

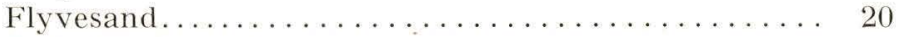

Postglaciale marine Dannelser............... 22

Postglaciale Ferskvandsdannelser.............. 23

Marsk. . . . . . . . . . . . . . . . . . . . 24

Klippegrund........................ 24

Danmarks Overgrund (C. H. Bornebusch) . . . . . . . 25

De almindelige Jordbundstyper. . . . . . . . . . . 27

Jordbundstypernes Fordeling . . . . . . . . . . . . . 29

The Surface Deposits of Denmark (Keld Milthers).... 34

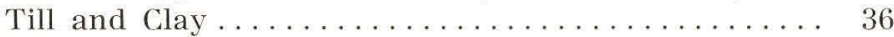

Diluvial Sand...................... 41

Outwash Plains ...................... 44

Late-Glacial Marine Deposits.............. 47

Dune Sand......................... 48

Post-Glacial Marine Deposits................ 49

Post-Glacial Freshwater Deposits............. 51

Marsh............................ 52

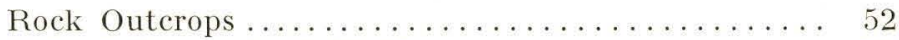

The Soil of Denmark (C. H. Bornebusch) . . . . . . . . 53

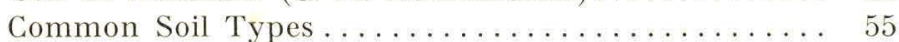

Distribution of Soil Types ............. 57

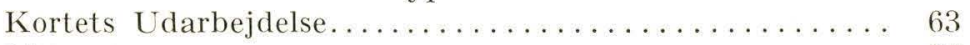

Litteratur.......................... 66 


\section{Fortale.}

en første Begyndelse til det nu foreliggende Jordbundskort over Danmark i 1:500000 maa søges i det Kort, der af den daværende Forstander for Statens forstlige Forsøgsvæsen, Professor, Dr. A. Oppermann og daværende Forstbiolog, Forstkandidat C. H. Bornebusch blev udarbejdet som det danske Bidrag til det Jordbundskort over Europa i Maalestokken 1:10000000, der af Det internationale Selskab for Jordbundsforskning i 1927 blev udgivet under Ledelse af Professor Dr. H. Strenne i Danzig. Da man kort Tid efter planlagde Udgivelsen af et Jordbundskort over Europa i Maalestokken 1:2500000 og i den Anledning henvendte sig til Professor Oppermann om det danske Bidrag til dette, forhandlede han om denne Sag med Direktøren for Danmarks geologiske Undersøgelse, Dr. Victor Madsen, og de kom da til det Resultat, at det ikke alene var meget ønskeligt, at Danmark ydede sit selvstændige Bidrag til det nævnte Europaskort, men ogsaa, at det ikke ringe Arbejde, som i den Anledning maatte udføres, blev gjort frugtbringende herhjemme ved, at der samtidig udarbejdedes og udgaves et Jordbundskort over Danmark i Maalestokken 1:500000. Til det i den Anledning nødvendige Arbejde i Marken og til det analytiske Laboratoriearbejde ansøgte de da Rask-Ørstedfondet og Carlsbergfondet om Bevillinger og erholdt fra det førstnævnte 5500 Kr. og fra det sidstnærnte $4400 \mathrm{Kr}$., medens Danmarks Geologiske Undersøgelse paatog sig at lade udføre Tegningen og Trykningen af Kortet og den til dette hørende Beskrivelse, imod at faa Ret til at udgive Kortet og Ejendomsret til Oplagene af dette.

Medens Professor Oppermarr satte Arbejdet i Terrænet i Gang og overvaagede dets Udførelse ved adskillige Rejser i Aarene 1928 og 1929, blev den egentlige Ledelse af dette overdraget dels til Statsgeolog V. Milthers og dels til den nuværende Forstander for Statens forstlige Forsøgsvæsen, Dr. C. H. Bonnebusch. Den geologiske Kortlægning og Udarbejdelsen af Kortets geologiske Del blev derefter udført af Mag. sc. Keld Milthers, som foretog de dertil nødvendige Undersøgelser i Marken i Aarene 1929, 1930 og 1932, medens Kortlægningen af Jordbundstyperne og Undersøgelsen af Jordbundsprofilerne blev udført af Skovriderne L. V. Krarup og Mørk Sørensen og Forstkandidat 
6 C. H. Bornebusch og Keld Milthers: Jordbundskort over Danmark.

Knud Ladefoged, idet disse blev indøvet i dette Arbejde af Dr. BorneBusch. Denne Kortlægning foretoges i Aarene 1928 og 1929, hvorefter Dr. Bornebusch udarbejdede Angivelsen af Jordbundstyperne paa Kortet.

Medens det danske Bidrag til det internationale Jordbundskort over Europa i Maalestokken 1:2500000 allerede kunde afsendes til Professor Stremme i April 1929, har forskellige Forhold, særlig Professor OpperMANNs Død 1931, forsinket Udførelsen af Jordbundskortet over Danmark i 1:500000, saa at dette først nu kan udgives.

Victor Madsen. 


\section{Danmarks Overfladelag.}

D anmarks Jordbund er saa at sige udelukkende dannet under og efter Istiden. Landets Overflade bestaar for en stor Del af Aflejringer, der er afsat under eller foran en Indlandsis; derimod er den ingen Steder opstaaet ved Forvitring af en Landoverflade, ældre end Istiden, saaledes som det oftest er Tilfældet i andre Lande. Gennemsnitlig har de kvartære Dannelser en Mægtighed af ca. $50 \mathrm{~m}$, men man har fundet, at de kan blive helt op til $200 \mathrm{~m}$ mægtige. Landets Udseende er derfor i saa høj Grad præget af Istidens Forløb. En Betragtning af Danmarks Jordbund bliver saaledes det samme som en Gennemgang af Kvartærtidens Aflejringer.

Underlaget under de kvartære Dannelser spiller dog ogsaa en Rolle for Landets Udseende gennem deres Niveauforhold, specielt hvor tektoniske Bevægelser har virket, f. Eks. hvor der findes Horste eller Spaltedale, eller hvor Klippegrunden træder frem saaledes som paa Bornholm.

Overlejrende Istidslagene (de glaciale og de interglaciale Lag) findes senglaciale Aflejringer d. v. s. fra selve Afsmeltningstiden, og postglaciale Aflejringer fra Tiden derefter, nemlig fra det Tidspunkt, da Plantevæksten havde bredt sig over Landet, indtil nu. Foruden efter Alder deles Vandaflejringerne ogsaa efter Stedet for deres Dannelse, nemlig i Havaflejringer (marine Lag) og i Ferskvandsdannelser. Begge disse Grupper indeholder igen forskellige Arter af Aflejringer, idet de marine Dannelser foruden egentlige Havbundsdannelser ogsaa omfatter Marsk, medens Ferskvandsdannelserne kan deles i de rent organiske (organogene) Tørveaflejringer og dels de øvrige Ferskvandsaflejringer, Dynd, Ler og Sand samt Kilde- og Mosekalk. Vindaflejringerne bestaar af Flyvesand, som baade kan være senglacialt og postglacialt, og som baade optræder langs Kysterne, mest som Klitter, og inde i Landet, som Indsande.

Danmarks Overflade er en Mosaik af kvartære Dannelser med de Lag, der er ældre end Kvartærtiden som Underlag. Istidslagenes tre store Hovedgrupper: Ler, Diluvialsand og Hedesand udgør Grundlaget i selve Mosaikken, og de yngre Lag, som frembyder en rig Variation, 
danner utallige Smaaomraader, der bryder de store Træk i Udbredelsen af de rene Istidsaflejringers nævnte tre Hovedgrupper.

Ser man bort fra alle de yngre Dannelser og holder sig til de tre typiske Istidsaflejringer: Ler, Diluvialsand og Hedesand, saa opdager man hurtigt, at en Linie, der i store Træk gaar fra Bovbjærg SV for Lemvig til Dollerup SV for Viborg og derfra mod Syd gennem hele den jydske Halvø, deler Jylland i to Dele, som er væsensforskellige. Syd og Vest for Linien er Sand overvejende; Hedesandet har inden for dette Omraade sin Hovedudbredelse, og i Omraaderne mellem Hedesletterne er Diluvialsand det overvejende. Nord og navnlig Øst for Linien er der fortrinsvis Ler, medens Sand kommer i anden Række; og af Sand spiller Hedesand her kun en underordnet Rolle. Denne Grænse, som med stor Tydelighed fremgaar af Jordbundskortet, er formet af Indlandsisen under sidste Nedisning, idet Isens Rand gennem en væsentlig Del af denne Istid havde sin Beliggenhed langs denne Linie, Hovedopholdslinien.

Landskabet i Vestjylland, der i sidste Istid laa uden for Isdækket, og som paa Grund af det arktiske Klima ikke havde noget Plantedække, blev ved Regnskyl og Jordflydning udjævnet saa meget, at de kuperede Terrænformer og afløbsløse Sænkninger blev sjældne eller helt forsvandt. I store Dele af Vestjylland bredte de udstrakte Hedesletter sig, idet Indlandsisens Smeltevandsfloder gradvis byggede dem op ved at afsætte Hedesand ud over dem. Hedesletterne hælder ganske lidt mod Vest og bærer ved deres Størrelse og Regelmæssighed Vidne om den lange Tid, deres Dannelse har varet.

Landskabet i Østdanmark og Nord-og Østjylland er ikke paa samme Maade udjævnet som i Vestjylland. Her findes langt brattere Skraaninger og langt mere vekslende Overfladeformer. Her er utallige smaa Gryder uden Afløb og en stadig Vekslen af store Flader med smaabakket Terræn. Her er langt dybere Dale og højere Bakker; her er ogsaa helt andre Kystformer end i Vestjylland; navnlig er Dalene med Langsøer og Sørækker karakteristiske for Øst- og Nordjylland. Hovedforskellen er, sagt med faa Ord, at i Vestjylland er Landskabet ældet, medens Landet Øst og Nord for Indlandsisens Hovedopholdslinie, der var isdækket under den sidste Nedisning, har bevaret sine ungdommelige Former.

Efter Istiden er der i enkelte Dele af Landet sket betydelige Andringer, særlig ved Landets Niveauforandringer; men overvejende har Udviklingen været den, at der i talrige, omend stærkt begrænsede Omraader er foregaaet en rolig Aflejring ved Vindens eller ved Vandets Hjælp. I de postglaciale Ferskvandsdannelser har navnlig Plantevæksten spillet en stor Rolle.

Efter denne orienterende Oversigt over nogle af Grundtrækkene i 
Landets Opbygning i Kvartærtiden skal vi betragte de enkelte Betegnelsers Betydning og Benyttelse paa det medfølgende Jordbundskort.

\section{Ler.}

Betegnelsen Ler omfatter de fleste af de Lerarter, der findes i Danmarks Overflade, idet heri er medregnet først og fremmest Moræneler og Diluviallér, men desuden ogsaa senglacialt Ferskvandsler. De to vigtigste af de Lerarter, der ikke er indbefattet i denne Gruppe, er det senglaciale marine Ler, Yoldialeret, i Vendsyssel, og Marsken, der forekommer langs det sydlige Jyllands Vestkyst.

Moræneleret eller Morænemergelen er den mest almindelige af de danske Lerarter. Det er selve det Materiale, som Indlandsisen har ført med sig fra de Omraader i Skandinavien, den har passeret henover, og aflejret ganske usorteret i den samme Blanding som den, i hvilken det forekom i Isen. Ved Opblanding med Kridt i Undergrunden har det faaet et Kalkindhold, der varierer mellem $10 \%$ og $30 \%$.

Dets Betydning for Landet kan billedligt anskues ved Betragtning af Kortets Landsbynavne; det er nemlig meget karakteristisk, at Tætheden af Landsbyer i Almindelighed er størst i de samme Omraader, hvor Moræneleret findes. Dette er i al sin Enkelhed et Udtryk for, at Moræneleret betinger Frugtbarheden i en saa overvejende Grad, at det giver sig direkte Udslag i Befolkningstætheden, bortset naturligvis fra Købstæderne, som for en Del er afhængige af andre Forhold.

Hovedudbredelsen af Moræneleret falder i nogen Grad sammen med Indlandsisens Udbredelse i sidste Istid. Det er dog ikke saadan, at der ikke findes Moræneler i Vestjylland, men her findes det fortrinsvis som spredte Partier og sjældnere som store sammenhængende Omraader, saaledes som i Østdanmark. I Vestjylland og navnlig i Sønderjylland findes Moræneleret undertiden i ca. 1 Meters Dybde, dækket af det saakaldte "Stenede Sand« (se Side 16). Jordbunden kan i Overfladen se temmelig mager ud, og dog er den præget af det vandstandsende Lag i den ringe Dybde; dette har navnlig Betydning for Trævegetationen, men det paavirker ogsaa i nogen Grad Agerbruget.

Nord og Øst for Isens Hovedopholdslinie i sidste Istid findes Hovedomraadet for Morænelerets Udbredelse. I Egnen omkring den vestlige Del af Limfjorden findes der store Landstrækninger med Moræneler; det er Aflejringerne fra den nordlige Isstrøm, der i sidste Istid dækkede Landet indtil Linien mellem Dollerup og Vesterhavet. I Vendsyssels Bakkeland findes der næsten ikke Moræneler som Overfladelag, derimod lidt Diluviallér. I den vestlige Del af Himmerland er Moræneler og- 
saa meget sjældent, medens der i Osthimmerland findes en Del langs med Lille Vildmoses Vestside. Fra Mundingen af Mariager Fjord til Randers findes der et Bælte med Moræneler. Den nordlige Halvdel af Djursland er meget mager, men fra en Linie omtrent fra Grenaa over Randers til Viborg begynder det store sammenhængende Bælte af Moræneler, der følger Jyllands Østkyst helt ned til den dansk-tyske Grænse.

De danske Øer bestaar overvejende af Moræneler, kun enkelte Egne har et stærkere Præg af Diluvialsand, dette gælder Sydvest-Fyn og Nordøst-Sjælland. Paa Laaland-Falster findes noget af det allermest fede Moræneler i Landet, det danner navnlig paa Laaland udstrakte Moræneflader. Paa Bornholm danner Moræneleret en sammenhængende Ring om Diluvialsandet i det indre af Øen.

De største Dele af Morænelersomraadet i Danmark er præget af store, rolige Landskabsformer. Den mest særprægede Form er Mor ænefladen, som træffes ret almindeligt baade paa Øerne og i Jylland. For at tage blot et enkelt Eksempel kan man nævne den Egn, der kaldes Heden, mellem København, Hedehusene og Køge:

„Bestaaende næsten udelukkende af Moræneler er Morænefladen karakteriseret ved sin ganske svagt bølgede, ligesom glattede eller strøgne Overflade. Afglatningen maa nærmest tænkes at være fremkommen ved, at Indlandsisen — samtidig med, at Morænematerialet udfældedes bevægede sig jævnt fremad, i hvert Fald indtil Isens Tykkelse var bleven saa ringe, at en yderligere Udfældning af Materiale under stillestaaende Is ikke kunde præge Overfladeformen og frembringe den urolige Karakter, der er Særkende for et Landskab, som er opstaaet under stillestaaende Is« (V. Milthers 1922).

Hertil kan tilføjes, at Fordampning af Isen maa have spillet en betydelig Rolle ved dens Forsvinden, idet Morænefladen ikke bærer nogetsomhelst Spor af Afløb for det Smeltevand, som en normal Smeltning maatte have medført. Hvor Indlandsisen til Slut har efterladt udstrakte Dødisdækker, træffer vi et mere uroligt Landskab. Den Landskabsform, der har sit Udtryk i Moræenefladen, maa da have sin Aarsag i, at Isen har holdt sig i Bevægelse, indtil dens Mægtighed blev saa ringe, at Fordampning alene kunde faa Bugt med den. Den bedste Forklaring paa den store Udbredelse af Moræneflade-Landskabet maa søges i et tørt og forholdsvis mildt Klimas kraftige Tæring paa Isdækket, medens dette endnu var i Bevægelse.

Til Moræneleret er ogsaa det smaabakkede Landskab meget ofte knyttet; det findes over adskillige Strækninger inden for Morænelersomraadet, selv om det ikke naar Moræneflade-Landskabet i Hyppighed. Det maa tænkes opstaaet under stillestaaende Is, hvor Morænematerialet i Isen har været meget ujærnt fordelt. Der har til forskellig Tid været fremsat forskellige Hypoteser om Dannelsen af dette Landskab; 
nogle af disse Hypoteser er baseret paa direkte Iagttagelser, medens andre er stærkt teoretisk prægede. Her skal eksempelvis nævnes nogle af de vigtigste Hypoteser, for at give et Indtryk af deres Forskelligartethed.

N. V. Ussing (1907) har paavist, at det smaabakkede Landskab i Egnen Syd for Lemvig og videre mod Øst indtil Egnen Nord for Alheden maa være opstaaet ved, at begravede Isklumper er smeltet. Ydergrænsen mod Syd for dette Landskab er Indlandsisens Hovedopholdslinie; mod Nord begrænses det af en Morænelinie, der er opstaaet ved en fornyet Aktivitet af den nordlige Isstrøm bag den døde Isbræmme. Smeltevandet fra den sidstnævnte, indre Morænelinie bag det smaabakkede Landskab vilde - hvis dette Omraade havde været isfrit - have virket stærkt udjævnende paa det; men da dette netop er meget stærkt kuperet, slutter Ussing deraf, at den kuperede Landskabsform her maa være opstaaet efter Isdækkets Forsvinden ved Eftersynkninger efter begravede Isrester, som var dækket af det Materiale, der blev afsat foran den bageste af de to Israndslinier.

K. GRIPP (1929) har paa Spitsbergen iagttaget krydsende Systemer af Lermure, der stod tilbage, efter at Isdækket var forsvundet. De dannede et veritabelt Aftryk af de Spalter i Isens Underside, der nedefra var blevet fyldt med Bundmoræne under Isens Tryk paa sit Underlag. I de Tilfælde, hvor dette Bundmorænemateriale bestod af Sand, skred Murene ved Smeltningen saa stærkt ud, at de kun i ringe Grad var fremtrædende i Landskabet, medens de, naar Materialet bestod af Ler, efterlod smaa Forhøjninger, der gav Landskabet et kuperet Præg. Disse Systemer af Spaltefyldninger opstaar ifølge GrIPP i nogen Afstand inden for Isranden som et Bælte, der følger Randen konformt; endnu længere inde end det kuperede Landskab opstaar da Morænefladen under den Del af Isen, hvor Spalterne er lukkede.

Poul Harder (1908) antager for Aarhusegnens Vedkommende, at det smaabakkede Landskab dér er knyttet til Isens Randzone, hvor Isens Mægtighed har været ringe og Bevægelsen saa svag, at Isen ikke har kunnet glatte Ujævnhederne i Bundmorænen ud. V. Milthers (1922) anser det for at være en Nødvendighed at antage, at Isen var stilleliggende medens det smaabakkede Landskab dannedes. Victor MadSEN (1928) antager ligeledes Isdækket for at have været stillestaaende; Fordybningerne er fremkomne dér, hvor Ismasser længst har holdt sig, Bakkerne dér, hvor Morænematerialet har samlet sig mellem Ismasserne.

Det smaabakkede Landskab er ikke udelukkende knyttet til Moræneleret, det findes ogsaa i mere magre Egne, undertiden med vekslende Sand og Ler; Morænefladerne kan derimod kun opstaa i genetisk Sammenhæng med Moræneler.

Det stenfrie Glaciallér, Diluvialléret, er ofte knyttet til Sænkninger 
i Overfladen, men dette er ikke paa nogen Maade en Betingelse for dets Forekomst. Det træffes ofte under tilsyneladende tilfældige Lejringsforhold over større eller mindre Omraader gaaende helt op til Overfladen eller i ringe Dybde. I de færreste Egne af Landet har Diluvialléret nogen større Udbredelse; i det sydvestlige Jylland forekommer Diluviallér dog paa en stor Strækning som den almindeligste Lerart. Dette Omraade er indgaaende beskrevet af Axel Jessen (1922). Han har paavist, at Diluvialléret i Sydvestjylland maa være afsat i Begyndelsen af en Interglacialtid under et forsvindende Isdækkes Afsmeltning, foran og i nær Tilknytning til Isens Rand. Diluvialléret her har senere været overskredet af en paany fremrykkende Indlandsis, som i nogle Tilfælde har forstyrret Lejringsforholdene, og som ofte har dækket det med Sand, Grus eller Moræneler. Undertiden findes Diluvialléret (inden for dette Omraade) ude paa Hedefladerne, det kan da enten være dækket af senglacialt Sand, eller det kan være blevet blottet ved Smeltevandets Erosion, saaledes at det fremtræder i Plan med Hedesletten og altsaa er en nederoderet Bakkeø. Eftersom Bakkeøerne i Sydvestjylland er fra næstsidste Istid, og dette Diluviallér er en Interglacialtid ældre end Bakkeøernes Overfladelag, maa det være afsat i Begyndelsen af næstsidste Interglacialtid og hører derfor til Slutningen af samme Istid som Morænen under Esbjerg Yoldialér. Det vil sige, at det tilhører den ældste af de her i Landet kendte to Interglacialtider.

Mange Steder i Landet findes andre Former for Diluviallér; en særlig Art er det saakaldte Issø-Ler eller Plateau-Ler (Fladbakkeler), der er aflejret i Søer, hvis Bund udgjordes af Landets naturlige Overflade, men hvis Sider for en større eller mindre Del har bestaaet af Is. Nogle Steder har kun selve Afløbet fra en naturlig Lavning været spærret af Isen, paa andre Steder har Issøerne paa de fleste Sider været omgivet af selve Isen, saaledes at Søens Bund ved Isens Forsvinden blev staaende som et mere eller mindre højtliggende Plateau eller undertiden som en Konsol, der støtter sig til Siden af en endnu højere Bakke. Der optræder saaledes i et Omraade mellem Odense, Middelfart og Assens en Mængde store, flade Konsoller, i hvilke den vandrette Overflade bestaar af fedt Diluviallér, som i rig Udstrækning anvendes i Egnens mange Teglværker. Se iøvrigt V. Miцthens (1931).

Plateau-Bakker findes i stort Tal i forskellige Egne af Nordsjælland, særlig udbredt findes de mellem Farum og Lillerød. V. MiLthers (1935).

Ved Egernsund (ved Graasten) findes der en meget betydelig Forekomst af Issø-Ler navnlig langs Sydsiden af Nybøl Nor, der har været opfyldt og aflukket af Is. Issøen er undersøgt af Sigurd Hansen. Ligeledes findes der ved Stenstrup paa Fyn Aflejringer fra en stor Issø; dens Sider udgjordes overvejende af naturlige Spærringer, men mod Nord og mod Sydvest kan Terrænet i sin nuværende Form ikke 
have dæmmet op for Vandet; der maa paa disse Steder have været Spærringer af Ismasser medens Søen eksisterede og Leret blev afsat. Leraflejringen i Stenstrup-Søen har vedvaret helt op i senglacial Tid, der findes nemlig planteførende Lag, Gytje, fra det varme Allerød Stadium i Senglacialtiden. Victor Madsen (1903) og V. Nordmann (1922).

I adskillige af de sidstnævnte Issøers Leraflejringer har man undersøgt Lerets Aarslag, Varvene, for at udrede deres Samhørighed og Tidsfølge. Det er dog ikke lykkedes at finde en sammenhængende Varvskala her i Landet, hvilket skyldes, at vore Diluviallér-Aflejringer findes i smaa, begrænsede Bassiner, der ikke tillader Sammenligning indbyrdes i større Stil, idet de hver for sig kun omfatter Aarsvarv fra ganske korte Aarrækker.

Diluviallér er gennemgaaende betydelig mere kalkholdigt end Moræneler. Medens Morænelerets Kalkindhold ligger mellem 10-30\%, er Diluviallérets Kalkindhold almindeligvis beliggende mellem 20-50\%. Diluvialléret udnyttes i langt højere Grad end Moræneleret til Mergling, da det oftere naar saa højt op i Kalkholdighed, at det betaler sig at udnytte det paa denne Maade.

Da Diluvialléret praktisk talt altid er stenfrit, egner det sig ofte fortrinligt til Teglværksbrug og anvendes i stor Udstrækning til Mursten. Næsten overalt, hvor der findes Diluviallér her i Landet, træffer man en livlig Teglværksindustri.

Senglacialt Ferskvandsler er paa Jordbundskortet ogsaa indbefattet i Betegnelsen Ler. Det forekommer rundt om i Landet i naturlige Sænkninger i Overfladen, men det spiller forholdsvis ikke nær saa stor en Rolle som de to foran nævnte Lerarter. Det findes dels som selvstændige Aflejringer, dels som Fortsættelse af glaciale SmeltevandsAflejringer, f. Eks. ved Stenstrup-Søen, men oftest træffes det som Bundlag i postglaciale Moser. Det indeholder ofte Rester af arktiske Planter, bl. a. af Dryas octopetala, efter hvilken det betegnes som Dryasler. Dets Udbredelse er ikke særlig stor, hvilket er en naturlig Følge af dets Begrænsning til de lokale Sænkninger i Overfladen. Det stammer ikke fra Isens Smeltevand, men derimod fra de Vandstrømme, der afledte Regnvandet og Snesmeltningen fra Overfladen af det isfrie, men kun i ringe Grad plantedækkede Landskab i senglacial Tid. Det er ikke meget forskelligt fra Diluvialléret og udnyttes paa samme Maade som dette.

Af væsentlig Betydning ved Brændingen af de Lerarter, der optræder i Danmarks Overflade, er deres Forvitringsgrad. Indtil en Dybde af $\mathbf{1}-2 \mathrm{~m}$ (undertiden 3-4 m) er Leret almindeligvis iltet og befriet for sit Kalkindhold. Ved Iltning af Jernforbindelserne farves Leret gulligt eller rødligt og kaldes da Rødler; det giver ved Brænding røde Sten i Mod- 
sætning til det dybere liggende, uforvitrede Blaaler, der giver gule Sten. Den tekniske Udnyttelse af de danske Lerarter er beskrevet af Johannes Andersen i »Oversigt over Danmarks Geologi« (1928).

De nævnte tre Lerarter: Moræneler, Diluviallér og senglacialt Ferskvandsler er paa Jordbundskortet slaaet sammen under Betegnelsen Ler. De øvrige Lerarter, som findes i Landet, er af forskellige Grunde ikke regnet med i denne Gruppe, men det kan dog være naturligt alligevel at nævne dem paa dette Sted.

I Jordbundskortets Signatur for Ler er ikke indbefattet:

Senglacialt marint Ler, der overvejende findes i Vendsyssel; det er paa Kortet ikke skilt ud fra de øvrige senglaciale marine Dannelser.

Postglacialt Ferskvandsler, der som Regel findes i Sammenhæng med Sand, Dynd, Gytje og andre alluviale Dannelser, som paa Kortet er sammenfattet under Betegnelsen "Enge«.

Postglacialt marint Ler, der her i Landet næsten udelukkende findes i Form af Marsk, som paa Kortet har faaet sin særskilte Betegnelse. Der forekommer dog ogsaa postglacialt marint Ler i de Landstrækninger, som ad kunstig Vej ved Inddæmninger og Udpumpning er tørlagte; disse Landstrækninger er indbefattet i de Omraader, der er afsat som postglaciale marine Dannelser.

Iøvrigt findes der i Danmark mange andre Lerarter, som for en stor Del ogsaa udnyttes, men da de kun rent undtagelsesvis og tilfældigt træffes i Overfladen, findes de ikke angivet paa Jordbundskortet. De ses undertiden i Klinterne, men som Regel skal man bore ned for at træffe dem. Ofte ligger de saa nær Overfladen, at man kan bryde dem i aabne Grave, og de anvendes da til Brænding af forskellige Slags Lervarer. Almindeligst er de tertiære Lerarter i Jylland, der har stor Udbredelse. Det fineste Pottemagerler faas fra de bornholmske RhætLias Lag. Som sagt, alle disse ældre Lerlag har ingen Udbredelse i Overfladen og findes derfor ikke medregnet i den paa Jordbundskortet som Ler betegnede Gruppe af Lerarter. Angaaende dem maa der henvises til J. P. J. Ravns Undergrundskort (1922).

\section{Diluvialsand.}

Paa Jordbundskortet omfatter Betegnelsen Diluvialsand baade Sand og Diluvialgrus; og endvidere er heri indbefattet Moræenesand og Morænegrus.

Diluvialsand er den mest udbredte Type af Sand, der findes her i Landet. Dets Kornstørrelse er meget varierende som Følge af, at det er afsat i rindende Vand i meget nær Tilknytning til Indlandsisen. Diluvialsand gaar jævnt over i Diluvialgrus, der undtagelsesvis kan 
blive meget groft. I Profiler ser man, at Diluvialsandets Lejringsforhold ustandselig har skiftet under Afsætningen. De enkelte Sandbænke griber ind over hinanden, og Lagstillingen er ofte stærkt hældende og udpræget diskordant. Inden for de enkelte Sandbænke ligger Lagene hovedsagelig parallelt, og Strukturen kaldes derfor paralleldiskordant. Strømstyrken har ligeledes været underkastet en stadig Variation, derfor er Kornstørrelsen saa stærkt varierende. Lag med fint, stenfrit Sand overlejres ofte af stenet Grus, der igen ofte kan overlejres af finere Sand. Variationen er næsten ganske ubunden, bortset fra, at Materialet altid er vandsorteret. Det er som Regel ganske renset for Lerbestanddele, hvilket skyldes den livlige Vandbevægelse under Afsætningen.

Der forekommer ofte Spring i Lagdelingen, idet Lagene enten har været udsat for Tryk efter deres Aflejring, stammende fra Is i Bevægelse, eller de har været aflejret oven paa begravede Isrester, som ved deres Smeltning har faaet Sandlagene til at sætte sig.

De Flodlejer, som har huset Smeltevandsfloderne, har haft meget skiftende Retninger, idet Issmeltningen til Stadighed har forandret Afløbsforholdene. Dette har medført, at Sandet findes aflejret uden Forbindelse med Terrænets nuværende Overflade, saa man kan ikke se, hvorledes Flodløbene har haft deres Bane. Sandet kan ligge ganske uregelmæssigt over store Arealer og som oftest tilsyneladende tilfældigt. Diluvialsandet forekommer netop hyppigst i stærkt bakkede Egne. Navnlig er det almindeligt i Randmorænestrøg, sammen med Diluvialgrus, Morænesand og Morænegrus, der, som nævnt, ikke paa Jordbundskortet er skilt ud fra Diluvialsandet.

Morænesand og Morænegrus er forøvrigt ikke særlig almindelige; men i Randmoræneomraader er de typiske og stærkt udbredte. De er uden Lagdeling og indeholder fra de groveste til de fineste Sten- og Kornstørrelser uden Sortering. Undertiden finder man saakaldte Blokpakninger med kolossale Mængder af Sten i Tilknytning til Randmorænerne.

Det viser sig ved Betragtning af Jordbundskortet, at der langs med nogle af de betydeligste Israndslinier findes særlig meget Diluvialsand inden for Omraader, der ellers hovedsagelig er præget af Moræneler. Sandet findes da som et Bælte langs med selve Israndslinien, bag hvilken Zone derpaa Moræneleret følger. Dette iagttages paa Jordbundskortet særlig tydeligt paa tre forskellige Steder: Bag den sidste Nedisnings store Hovedopholdslinie fra Dollerup mod Syd; langs den østjydske Israndslinie i en Bue uden om Bugten ved Aarhus; og endelig i en Bue omkring Køge Bugt, konform med Isens Randstilling dér.

Diluvialsandet er ogsaa knyttet til et specielt Omraade, der landskabeligt hører til i Morænelersomraaderne, nemlig de langstrakte og meget smalle Bakker, Aasene, der findes i Østdanmark inden for den 
sidste Nedisnings Omraade. De er ofte stærkt fremtrædende i Landskabet, naar de, hvad der er det almindelige, omgives af roligt Terræn med leret Jordbund. Ved deres skarpe Form og sandede eller grusede Indhold vækker de altid stor Opmærksomhed. De er opstaaet i direkte Berøring med Isen, som Regel i Flodløb i Kanaler i Isen. Dannelsesmaaden for Aasene er iøvrigt meget forskellig, og alle Forsøg paa at generalisere en enkelt Forklaringsmaade er hidtil strandet paa den rige Mangfoldighed i Opbygningen, som Aasene bærer Vidne om.

Aasenes Retning er ofte parallel med Isens Bevægelsesretning i det paagældende Omraade, og de repræsenterer da Isens store Smeltevandsfloder. I Fortsættelse af Aasene træffer man undertiden Partier af Flodens Løb, hvor den inde under Isen har gravet sig ned i Underlaget og dannet dybe, langstrakte og uregelmæssige Dale, de saakaldte Tunneldale. De smukkeste Tunneldale findes i Østjylland, hvor de nu dels udgør de østjydske Fjorde og dels de fleste af de Aadale og LangsøRækker, der fortsætter sig mod Vest fra Fjorddalene ind imod Indlandsisens Hovedopholdslinie; her munder de ud i Hedesletterne, som er opbygget af Aflejringer fra Tunneldalenes Smeltevandsfloder.

Paa Øerne er Aasene lige saa hyppige som Tunneldalene, de findes ofte begge kombineret langs det samme subglaciale (d. v. s. under Isen opstaaede) Flodløb. Paa Jordbundskortet træder enkelte af de største Aase frem, fordi de har en saadan Størrelse, at deres Sandaflejringer har kunnet indgaa som et selvstændigt Omraade. Paa Sjælland bemærker man Mogenstrup Aas (ved Næstved) og Køge Aas.

Det er dog de færreste danske Aase, der har kunnet komme med paa Kortet, da deres Udbredelse navnlig i Bredden er saa ringe, at man ikke uden at fortegne Billedet har kunnet afsætte dem. Desuden er de ofte ikke afvigende fra den omgivende Jordbund, idet der ogsaa findes Sand i de tilstødende Omraader; eller, som det f. Eks. er Tilfældet med Sallinge Aas paa Fyn, Aasen er mange Steder dækket af en Kappe af Moræneler, hvorfor den paa Kortet ikke kan skilles ud fra Omgivelserne.

Sand, Grus og Sten anvendes til Beton- og Mørtelblandinger, samt til Vejbygning og Vandfiltre. Specielle Sandtyper anvendes af Støberierne til Formsand.

Den mest almene Udbredelse inden for en enkelt Egn har Diluvialsandet i Himmerland, hvor det er den overvejende Jordbund. Bortset fra Østhimmerland er leret Jordbund ret sjælden i Himmerland. I Vendsyssel bestaar de højt liggende Bakkedrag næsten udelukkende af Sand.

I Vestjylland er Sandet stærkt udbredt; det er for en meget stor Del Diluvialsand, men man har for denne Landsdels Vedkommende ofte at gøre med en Form for Sand, der betegnes som: Stenet Sand; det er uden Lagdeling og meget kalkfattigt. Dets Oprindelse tolkes forskelligt; 
dels mener man, at det er en Overflademoræne, som paa Isens Overflade har været Genstand for en kraftig Udvaskning, der har fjernet Kalk og Ler saavel ved Vandets som ved Vindens Hjælp (VICTOR MADSEN, 1928); dels forklarer man det som Resultat af en Forvitringsproces, hvorved Overfladelaget er afkalket og gennem det nedsivende Vand befriet for sit Lerindhold (A. RosenkRantz, 1933). Der er dog ogsaa en tredie Mulighed, nemlig at dette Overfladelag -- der i Vestjylland, hvor det har sin Hovedudbredelse, efter sin Dannelse har oplevet en hel Glacialtid (foruden to Ikke-Glacialtider) og derfor i længere Tid har været udsat for et arktisk Klima, som dels har hindret Plantevæksten og dels har fremmet de fra arktiske Egne kendte Forhold i Jordskorpen - maa have faaet sit ejendommelige Præg som Følge af den saakaldte »Brodelbewegung«, hvorved Jordens øverste Lag sættes i en Art »kogende« Bevægelse. Under denne Bevægelse kan det netop tænkes, at de forskellige Dele af Jordsmonnet er blevet befriet for deres Lerindhold, efterhaanden som de er kommet op til Overfladen, og at deres Kalkindhold er blevet udvasket, samtidig med at Stenindholdet er blevet udsat for Sandflugtens afslibende Virksomhed og har faaet den sandslebne Form, som er ejendommelig for Stenene i det Stenede Sand.

\section{Hedesand.}

Hedesand kaldes med et uheldigt Udtryk ofte for senglacialt Sand; dette maa ikke opfattes saaledes, at Hedesandet kun stammer fra selve Senglacialtiden, det er nemlig overvejende dannet i den sidste Istids mest udpræget glaciale Afsnit som Smeltevandsflodernes Aflejringer foran Isranden. Udtrykket »senglacialt« Sand dækkes som Regel af Betegnelsen: ekstramarginalt Sand (d. v. s. afsat uden for Randen), i Modsætning til Diluvialsand og Morænesand, der er afsat i direkte Tilknytning til Isranden.

Smeltevandsfloderne har afsat deres Materiale under to forskellige Former, der er betinget af Afløbsforhold, Materialemængde, Strømstyrke og maaske navnlig af Afsætningens Varighed. De to Former, i hvilke de ekstramarginale Aflejringer forekommer, er Hedesletter og ekstramarginale Dales Terrasser.

Hedesletterne er opstaaet som store Sandaflejringer, der er afsat foran Indlandsisen af Smeltevandsfloderne paa samme Maade, som Smeltevandsfloderne fra Gletsjere, f. Eks. paa Island, den Dag i Dag af Sand og Grus opbygger store, flade Sletter foran deres Rand. Sandet er aflejret paa Landets oprindelige Overflade; det har opfyldt Lavningerne og formet Landskabet om, saa at det nu fremtræder med store, vidtstrakte Sletter, der er næsten vandrette. Disse er opbyggede af 
ganske flade Kegler, hvis Toppunkter findes ved Smeltevandsflodernes Udløb fra Indlandsisen, og de har en ringe Hældning, ca. 1 : 500, hvilket er overordentlig lidt. De tager sig derfor ud, som de virkelig var vandrette; og paa Grund af deres Størrelse, og fordi de ofte er lyngbevoksede, har de tidligt tiltrukket sig Opmærksomhed som et ejendommeligt, og navnlig for Vestjylland særpræget Landskab.

Jordbunden er stærkt udvasket af Smeltevandsfloderne, og gennemsivende Regnvand har derfor senere haft let Adgang til yderligere Udvaskning; de dermed sammenhængende Aldannelser har gjort, at Heden ikke i tidligere Tid har været Genstand for ret stor Opdyrkning. Derfor er de egentlige Hedesletter ikke saa stærkt befolkede, hvilket ogsaa fremgaar af Kortet, idet der er langt færre Landsbynavne paa Hederne end i de lerede Egne; der er ogsaa flere Landsbynavne, saa snart Jordbunden i Stedet for Hedesand bestaar af Diluvialsand.

Lagdelingen i Hedesandet er tilnærmelsesvis vandret, idet den følger den jævne Overflade, der, som nævnt, har overmaade ringe Fald. Der er ikke den Uro i Lagstillingen som hos Diluvialsandet; det hænger sammen med, at Hedesandets Aflejring er foregaaet ganske roligt. Man betegner Hedesandets Lagdeling som horizontal og konkordant.

Størrelsesforholdene af Sandkornene i Hedesandet er mere ensartede end i Diluvialsandet; det hænger sammen med, at Vandsorteringen er langt mere gennemført af de Floder, der har strømmet ud over Hedesletterne. Vi træffer her navnlig to fremherskende Kornstørrelser, dels de almindelige Sandkorn, som er transporteret opslæmmet i Vandstrømmen til det Sted, hvor de er sunket til Bunds, og dels de flade Smaasten, der er transporteret af Bundstrømmen i Smeltevandsfloden rullende langs Bunden til det Sted, hvor de nu findes. I. A. Udden (1914) har for Floders Vedkommende paavist, at der bestaar et konstant Størrelsesforhold paa 16:1 mellem de Sten, der rulles langs Bunden af en Vandstrøm, og de Korn, der holdes opslæmmet, men som er paa Grænsen til at udfældes af den samme Vandstrøm. Forholdet er ikke undersøgt for det danske Hedesands Vedkommende, men der synes at bestaa et lignende konstant Forhold mellem de to fremherskende Kornstørrelser, og det er derfor nærliggende at antage, at Aarsagen er den ovennævite.

Den anden Gruppe af Hedesandsaflejringer er de ekstramarginale Floddales Terrasser, der indeholder samme Materiale som Hedesletterne. Langs næsten alle de større danske Aaer findes disse Terrasser, der bærer Vidnesbyrd om, at Dalen er anlagt af Smeltevand i Istiden. Dette gælder saavel de Dale, der er skaaret ned i Hedesletterne under de sidste Stadier i disses Dannelse, som de større Aadale i det øvrige Danmark. De vigtigste af de Aaer, der repræsenterer Hedeslettedannelsernes Slutstadier, er Skive Aa, Storaa, Skjern Aa med sine Tilløb 
Brande Aa og Omme Aa, og Hvidaa. Til de selvstændige, ekstramarginale Dale hører f. Eks. Kongeaa Dal, der repræsenterer en virkelig Hedeslette, men som paa Grund af sin langstrakte Form mere minder om en Floddal.

Under Isens Afsmeltning fra Egnen Syd for Limfjorden har der været en Række Stadier med Afløbsdale i forskellige Baner, efterhaanden som Isen tillod Vandet fra den østlige Isstrøm at finde sig Udløb i. andre Retninger end ud over Karup Hedeslette (N. V. Ussing 1903, 1904, 1907 og Keld MrLthers 1935). Saalænge Indlandsisens Rand laa ved Hovedopholdslinien, kunde Smeltevandet komme mod Vest over dette jydske Hovedvandskel, men da Isen trak sig bort fra denne Linie, var Floderne ikke i Stand til at overskride det, og derved blev Forandringerne i Afløbsforholdene betydelige. Da Isen gav efter i Egnen Nord for Alheden, søgte Smeltevandet denne Vej ud og dannede Karup Dal med Afløb til Limfjorden over Dødis i Venø Bugt; da Venø Bugt senere blev isfri, skar Karup Flod sit Leje dybere ned i Hedesletten, hvorved de to Terrasser langs Skive Aa (Karup Aa) dannedes. Lidt senere dannedes noget østligere den nu helt udtørrede »Falborg Dal«, der gaar omtrent fra Silkeborg nordpaa langs Gudenaa til Tange, derfra mod Vest, Syd om Viborg over Viborg Hede og Revn Hede (to brede Flodsletter) til Hjarbæk Fjord, hvor Udløbet fandt Sted over begravet Dødis. »Falborg Dal afløstes direkte af Gudenaa-Skalsaa Dal, der ligeledes havde Afløb udover Isen i Hjarbæk Fjord. Da Isen i Fjordene Ost for Salling smeltede bort, dannedes Skive Aas nuværende Udløb til Skive Fjord, idet Floden umiddelbart Syd for Skive gennemskar sin egen Terrasse, fordi Vandet ikke mere behøvede at løbe over mod Vest til Venø Bugt, men kunde søge ud til den frigjorte Skive Fjord. Nogen Tid efter, at disse Fjorde var blevet isfrie, smeltede Isen ved Randers bort, saaledes at Vandet fra Gudenaa Dal ikke mere blev tvunget over i Skalsaa Dal, men fik sit nuværende Udløb ved Randers. Omtrent samtidig smeltede Isen i Egnen ved Silkeborg saa meget bort, at Gudenaas øvre Løb blev udviklet. Gudenaas lange Flodsystem tjente senere til Afløb for en Del af Smeltevandet fra den Is, der ved et senere Fremstød dannede den af Poul Harder (1908) beskrevne » Østjydske Israndslinie«. Til denne Israndslinie svarer desuden nogle Afsmeltningsdale i Djursland, der nu fremtræder som højt liggende Hedesand-Terrasser. Ved Smeltevandsflodens Udspring ved Glatved Syd for Grenaa aflejredes kolossale Mængder af grove Rullesten, for en stor Del bestaaende af Saltholmskalk.

Alle disse ekstramarginale Afsmeltningsdale har betydet uhyre meget for Dræneringen af Jylland. Paa Øerne findes ogsaa Terrasser med Hedesand langs nogle af de største Aaer f. Eks. Odense Aa og Susaas øvre Løb; Susaa havde i Afsmeltningstiden Udløb gennem Aamose og Saltbæk Vig til Sejrø Bugt. Smaa Flodsletter findes paa Fyn mellem Odense 
og Nyborg, og paa Sjælland Syd for Arresø; desuden findes der talrige Smaaomraader rundt omkring i Landet.

Undertiden træffer man senglacialt Søsand; mest kendt er Sandet omkring det stenfrie Ler ved den ovenfor omtalte Stenstrup Sø paa Fyn.

\section{Senglaciale marine Dannelser.}

Vendsyssel laa i Slutningen af den sidste Istid betydeligt lavere end nu; det fremtraadte dengang som en Gruppe af større og mindre Øer. I Havet mellem Øerne afsattes paa dybere Vand Yoldialér, og i Strandkanten afsattes det øvre Saxicavasand, der, efterhaanden som Landet hævede sig, bredte sig over større og større Omraader. Saxicavasandet dækker nu over store Strækninger Yoldialeret, som dog altid ligger ret nær under Overfladen og ogsaa mange Steder gaar frit i Dagen. Dér, hvor der under Sænkningens Maximum var Kyst, hviler Saxicavasandet direkte paa de glaciale Dannelser.

Hævningen blev en kortere Tid afbrudt af en ny Sænkning, i hvilken der $i$ et mindre Omraade afsattes Zirphæasand.

Den senglaciale Havbund fremtræder nu som ret højtliggende Plateauer, der i Vendsyssel udgør en væsentlig og meget karakteristisk Del af Landskabet.

Plateauerne ligger indtil 30-34 m over Havet i det nordøstlige Vendsyssel, hvor Hævningen efter Senglacialtiden har været størst. Den højeste Strandlinie i hele det hævede Omraade ligger $56 \mathrm{~m}$ over Havet, den findes Syd for Frederikshavn. Højden aftager stærkt mod Sydvest, indtil en Linie fra det østlige Thy over Djursland; langs denne Linie er Hævningen lig Nul. (AxeL Jessen, 1918).

Yoldialeret udnyttes navnlig i Egnen omkring Nørresundby og Aalborg, hvor det sammen med Kridtet bruges til Cementfremstilling.

Paa Bornholm er Signaturen »Senglaciale marine Dannelser « anvendt paa en maaske lidt misvisende Maade til at betegne Aflejringer fra den baltiske Issø. I Senglacialtiden var den sydlige Del af den baltiske Dal saa højt beliggende i Forhold til Havet, at de var adskilte, og der fandtes da her en Issø, som havde Afløb til Havet ad skiftende Veje. Vandet var en Tid stemmet saa højt op, at Bornholms lavere Partier tildels var dækket af Søen. Der blev derved afsat Mærker i en Højde af 9-10 m o. H. langs Sydkysten og i en Højde af 20-21 m o. H. ved Hammeren. Aflejringerne er Strandsten og Strandvolde.

\section{Flyvesand.}

Hovedomraadet for Forekomsten af Flyvesand i Danmark er Jyllands Vestkyst i hele sin Længde. Klitterne findes i et Bælte af varierende 
Bredde, indtil $10 \mathrm{~km}$, og Klitdannelsen er heller ikke lige stærk overalt. De mest udprægede Klitlandskaber i Jylland forekommer Nord for Limfjorden; navnlig er Skagens Gren bekendt for den store, hvide (ubeplantede) Klit Raabjerg Mile (Studeli Mile), der faar Lov til at vandre østover uden Indgreb fra Menneskenes Side. Ellers er de fleste Klitter enten ad naturlig Vej eller ved Menneskenes Hjælp blevet bevoksede, saaledes at Sandflugten er indskrænket til et Minimum. I Han Herrederne mellem Jammerbugt og Limfjorden findes smukt udviklede Parabelklitter med Aabningen imod Vindretningen; de er opstaaet ved gentagne Vindbrud i bevoksede, saakaldte graa Klitter.

Ogsaa inde i Landet, i lang Afstand fra Kysten findes Klitter; de er alle bevoksede og stammer fra gammel Tid. Adskillige af disse saakaldte Indsande blev dannet paa det isfrie Land umiddelbart foran Isen eller i selve Senglacialtiden. Ofte findes disse Indsande paa Hedesletterne, undertiden forekommer de ved Udspringet af en ekstramarginal Flod; dette er f. Eks. Tilfældet med Vrads Sande, der ligger i den glaciale Storaa Dals Udspring ca. $15 \mathrm{~km}$ Syd for Silkeborg. Nogle Indsande er opstaaet i historisk Tid ved Vindbrud i Hedernes Lyngskjold.

Paa Jordbundskortet er kun de Indsande medtaget, der fremtræder som Klitter. Der findes dog ogsaa Flyvesand inde i Landet, som ikke er aflejret i Klitform; det er ved de geologiske Kortlægninger paavist, at der undertiden kan ligge Flyvesand som ganske flade Drkker, der ikke gør Landskabet afvigende fra det omgivende Land. Den sandsynlige Forklaring paa disse Aflejringer er, at Sandet er blevet bundet af Fugtigheden i de lavt liggende Omraader, og derfor ikke har kunnet fyge sammen til Klitter, saaledes som det sædvanligvis er Tilfældet med Flyvesand. Disse Omraader, hvor kun Jordbunden, men ikke Landskabet, har faaet Præg af Flyvesandet, er ikke særlig almindelige, og da de heller ikke jordbundsmæssigt spiller nogen Rolle, er de ikke indbefattet i de som Flyvesand markerede Omraader, men optræder med samme Betegnelse som deres Omgivelser, det vil næsten udelukkende sige Diluvialsand og Hedesand.

Ligesaavel som i Jylland findes der ogsaa, ganske vist smaa, Flyvesandsomraader paa Øerne. Foruden paa de sandede Øer Læsø og Anholt findes det ogsaa paa de mere lerede danske Øer: ved Frøs Sydspids, ved Ristinge paa Langeland, langs Sjællands Nordkyst, særlig i Egnen ved Tisvilde-Melby Overdrev og endelig de betydelige Flyvesandsaflejringer ved Dueodde og andre Steder paa Bornholm.

I det 16. og 17. Aarhundrede har Sandflugten anrettet store Ødelæggelser paa Jyllands Vestkyst og f. Eks. ved Tisvilde og paa Bornholm samt flere andre Steder. 


\section{Postglaciale marine Dannelser.}

I Stenaldertiden blev Danmark truffet af en Sænkning af Landet, der gjorde Fjordene dybere og fik dem til at strække sig ofte betydelig længere ind i Landet end nu. Dette medførte ændrede Livsbetingelser for Havets Fauna, og da der samtidig indtraf et Varmemaksimum, blev Dyrelivet i Fjordene rigere. Stenalderfolket levede den Gang i nær Tilknytning til Havet, og vi træffer i den første Del af Stenalderhavets Tid deres Skaldynger liggende langs Kysterne af de tidligere Fjorde. Det daværende Hav benævnes Litorina-Havet eller TapesHavet.

De marine Aflejringer fra denne Tid træffes i de lavt liggende Partier i de nordøstlige Dele af Landet. Kun den sydvestlige Del af Landet, SV for en Linie fra Nissum Fjord til Middelfart og derfra over Nordspidsen af Langeland til den nordlige Del af Falster, er ikke blevet hævet op over Litorina-Havets Niveau.

Den største Hævning træffes ved Frederikshavn, hvor Landet nu er hævet til 13 m over Stenalderens Niveau. Herfra aftager Højden jævnt imod Sydvest til den før omtalte Linie, hvor Hævningen er lig Nul.

Randers Fjord gik omtrent ind til Viborg, man har fundet postglaciale marine Aflejringer i Nørreaa Dal helt ind til Brunshaab, $4 \mathrm{~km}$ sø for Viborg. Vendsyssel blev ogsaa ved denne Sænkning adskilt i forskellige Øer, dog blev det ikke saa stærkt opdelt som i Senglacialtiden, da Sænkningen ikke var nær saa betydelig som i denne. De postglaciale marine Aflejringer ligger derfor i et Bælte udenom de senglaciale marine Aflejringer i Vendsyssel. Det meste af Han Herrederne og hele den vestlige Del af Thy laa i Stenalderen under Vandet; store Dele af de hævede Arealer er nu dækkede af Flyvesand, og de med Signaturen for Flyvesand betegnede Strækninger hører for en stor Del til de Omraader, der har deltaget i Litorina-Sænkningen. Endvidere var Skagens Gren, samt baade store og lille Vildmose nedsænkede. Kolindsund i Djursland strakte sig gennem Halvøen fra Kattegat til Randers Fjord, og saaledes kunde man nævne utallige Forandringer fra Stenalderhavets Tid, bl. a. ogsaa i Nordsjælland. For det nordlige Jyllands Vedkommende kan henvises til AxeL Jessen (1920); en samlet Oversigt over Hævninger og Sænkninger er givet af AxEL JEssen i "Oversigt over Danmarks Geologi« (1928) og af E. L. Mertz (1924).

Sænkningen i Stenaldertiden var ikke særlig stor, og de Aflejringer fra Stenalderhavet, der nu er hævet over Havet, er derfor Kyst- eller Lavtvandsdannelser. Det drejer sig langt overvejende om Strandvolde og ellers om sandede Aflejringer, sjældnere om Dynd.

De almindeligste postglaciale marine Dannelser er de sædvanlige Stranddannelser, der navnlig i Vestjylland kan indtage store Arealer. 
Langs hele Vesterhavets Kyst findes et bredt Strandbælte med overvejende fint Strandsand indenfor selve Rullestensbæltet, der ligger i Havstokken. Strandsandet blæses af de hyppige og stærke Vestenvinde sammen i Klitter, der danner et mere eller mindre bredt Bælte lige inden for Strandfladen.

Meget almindeligt finder man de hævede Havstokke som Strandvolde, der ofte udgør ret store Arealer med hele Systemer af næsten parallele Volde. De er frembragt dels som Følge af selve Hævningen, $o g$ dels som en naturlig Udvikling af deres egen Udvidelsestendens, idet de beskytter de allerede indvundne Omraader og stadig breder sig over nye.

Ved Havets Strømninger, hvor der findes Indskæringer i Kysten, kan der dannes Odder og Tanger, som tilsidst forvandler Indskæringerne til Indsøer, der kun har en snæver Forbindelse med Havet. Saaledes er adskillige af de jydske Indsøer langs Vesterhavet opstaaet.

Naar Odderne strækker sig saa langt ud, at de naar at forbinde undersøiske Rev med det faste Land, kan der opstaa saadanne Landomraader som Skagens Gren, hvor Strandvoldene nu danner kæmpemæssige Systemer, der viser, hvorledes Strømningerne i Havet har formaaet at skylle saa meget Materiale op i Voldene, at der er dannet en meget betydelig Udvidelse af Landomraadet (AxeL Jessen »Vendsyssels Geologi« 1918).

Langs Danmarks Kyster er der ved Kunst indvundet ret store inddæmmede Arealer, som nu udnyttes til Agerdyrkning. Mange Vige, Bugter og enkelte Fjorde er omdannet til frodig Agerjord. Bunden er meget forskelligartet, nogle Steder er den meget sandet, andre Steder er den leret og fed. Skønt disse Omraader ikke ved Naturens egen Kraft er hævet over Havfladen, (tværtimod ligger de indtil flere Meter under Havets Niveau), maa de dog henregnes til de postglaciale marine Dannelser, og er derfor paa Kortet slaaet sammen med disse. En udførligere Omtale af de inddæmmede Arealer er givet af V. Mrtthers (1925) i Afsnittet »Danmarks Jord« i »Det danske Landbrugs Historie«.

\section{Postglaciale Ferskvandsdannelser.}

Paa Jordbundskortet er der blandt de postglaciale Ferskvandsdannelser skelnet imellem Moser og Enge. Denne Adskillelse er ikke let at gennemføre; den udtrykker i første Række, hvilke alluviale Ferskvandsdannelser, der udnyttes til Tørveskæring eller egner sig til det, og hvilke der udnyttes paa anden Maade eller henligger ubenyttede.

Betegnelsen Moser omfatter dels Tilgroningsmoser (Sømoser og Aamoser), der navnlig indeholder Kærtørv, dels Forsumpningsmoser, hvortil de egentlige Højmoser, der overvejende er opbygget af Tørvemos 
(Sphagnum), hører. Signaturen Enge omfatter alle øvrige alluviale Ferskvandsdannelser, saasom Dynd, Sand og Ler samt Kilde- og Mosekalk.

Ferskvandsaflejringerne er ligeligt fordelt over hele Landet; dog eksisterer Kilde- og Mosekalk som Følge af deres Oprindelse i nær Tilknytning til kalkholdigt Vand ikke uden for sidste Nedisnings Grænse.

Langs Aaløbene er Signaturen for Moser eller Enge sat, naar Aadalen er saa bred, at det teknisk set er muligt at fremstille den paa Kortet uden at fortegne Billedet, saaledes at Signaturen breder sig ind over Omgivelserne. Da Aadalene ofte er saa smalle, at de ikke vil kunne ses paa Kortet i dets Maalestok, er der undertiden Afbrydelser i Billedet af Ferskvandsaflejringerne langs Vandløbene. Se iøvrigt Knud Jessen (1918 og 1920).

\section{Marsk.}

Langs den sydlige Del af Jyllands Vestkyst foregaar en stadig Paalejring af fedt marint Ler, det saakaldte Marsklér; det lægger sig ved Flodtid som et Bundfald af Havvandet, der efterlader det fede Ler hængende i Planterne og Smaadyrene ved Ebbetid. Dannelsen af Marsken forskyder sig stadig, dels fordi Marskens egen Vækst faar Overfladen til at ligge højere, dels fordi en vedvarende Landhævning efter en midlertidig Sænkning i Tiden efter Broncealderen efterhaanden tørlægger de allerede dannede Marskarealer; Hævningen andrager 1,21,4 m siden Broncealderen. (AxeL JEssen »Marsken ved Ribe« 1916).

\section{Klippegrund.}

Betegnelsen Klippegrund findes kun paa Bornholm, idet det er det eneste Sted i Landet, hvor der findes Undergrund gaaende i Dagen, som bestaar af fast Fjæld.

Det er overvejende inden for Granitomraadet, at Underlaget træder frem uden Beskyttelse af kvartære Lag. Dette hænger bl. a. sammen med, at Granitomraadet, der udgør de nordøstlige to Tredjedele af Landet, danner Stødsiden af Øen, medens de sedimentære Dannelser fra Jordens Oldtid og Middelalder findes paa dens Læside i Forhold til Isstrømmene.

Der er ikke paa Kortet skelnet mellem forskellige Slags Undergrund. Angaaende denne maa der henvises til V. MiLthers (1930) og for Grundfjældets Omraade til K. Callisen (1934). 


\section{Danmarks Overgrund.}

Medens man i Geologien beskæftiger sig med Jordens Opbygning af de forskellige Bjergarter, er det Jordbundslærens specielle Opgave at studere den Del af Jordskorpen, som er Basis for Jordens Planteliv. Jordbundsforskeren beskæftiger sig med Overgrunden, d. v. s. de allerøverste Jordlag, som ved Indvirkning af Klima og Plantevækst har gennemgaaet en væsentlig Forandring, og i hvilken Planternes Rødder i Hovedsagen udbreder sig.

Al Landjordens Plantevækst, bortset fra Klippernes Liken- og Mosvegetation, er direkte eller indirekte afhængig af en Overgrund, i hvilken alle højere Planter (med Undtagelse af nogle Snyltere og Epifyter) er fæstnede med deres Rødder, og Overgrunden er derfor næst efter Klimaet den væsentligste bestemmende Faktor for Vegetationen. Medens Klimaet drager de store Linier for Jordklodens forskellige Vegetationstyper, er det Jordbundens Art og Fugtighedsforhold, der indenfor mindre Omraader betinger det naturlige Plantedækkes Vekslen fra Sted til Sted.

Virkningen mellem Jordbund og Plantevækst er imidlertid gensidig. En meget væsentlig Bestanddel i Overgrunden, især i dens øverste Lag, er nemlig Humus, organisk Stof opstaaet af døde Organismer, især af Planterne og deres affaldne Løv. Da de forskellige Plantearters Affald omsættes ulige let og giver Anledning til forskellige biologiske Forhold i Jordsmonnet, er "Humustilstanden« stærkt afhængig af Plantevæksten.

Man skelner her i Landet mellem to almindelige Humustyper: Muld og Mor, og to Overgrundstyper: Brunjord (Sialit) og Podsol.

I udpræget Muld er den af Planteaffaldet dannede Humus inderligt blandet med Mineraljorden. Denne Blanding sker i Hovedsagen paa den Maade, at Regnormene trækker Planterester ned i deres Gange og fortærer dem naar de er blevet møre; desuden sluger Regnormene en Mængde Jord, og deres Udtømmelser, som de aflægger paa Jordoverfladen, bestaar af en Blanding af Humus og Mineraljord. Hvor der er et rigt Regnormeliv, vil hele Jordoverfladen være dækket af et Lag af saadanne Klumper, af hvilke i Virkeligheden hele det øverste Jordlag er opstaaet, og Muldlaget gaar her jævnt over i Mineraljorden. 
Ved mere overfladisk Arbejde, af mindre Regnormearter, faas en grynet, meget humusrig Muld lejret ovenpaa Mineraljorden. Humusstofferne er ogsaa her blandet med Mineraljord, men ikke i saa stor Mængde at det fremtræder tydeligt for Øjet.

Humustypen Mor udmærker sig ved, at Indblanding af Mineraljord mangler eller i alt Fald kun er yderst ringe. Moren danner altid et fra Mineraljorden skarpt afgrænset Lag paa Jordoverfladen. Dens Opstaaen skyldes langsom og ufuldstændig Omsætning af de organiske Affaldsstoffer uden Medvirkning af saadanne dyriske Organismer, der som Regnormene formaar at blande Humus og Mineraljord sammen. Moren bestaar øverst af et løst Lag af Blade, Naale og andet, i livlig Omsætning og mer eller mindre sønderdelte (F-Lag $=$ Fermentationslag) og derunder af en tættere, mer eller mindre sammenhængende og finkornet Humusmasse (H-Lag = Humificerede Lag). Den er en Slags Tørvedannelse paa det tørre.

Af de to Overgrundstyper er Brunjorden normalt knyttet til Mulden, medens Podsol er knyttet til Mor. Under Paavirkning af det nedsivende, kultveilteholdige Regnvand foregaar der en Forvitring af Jordens Mineraler. Særlig let opløses den kulsure Kalk, som efter Istiden var indblandet rigeligt overalt i Aflejringerne fra den Is, som havde passeret Østersøen, medens de nordøstlige Egne af Jylland og Nordsjælland, hvis Materiale kom nordfra, var temmelig kalkfattige. Denne Forskel ses endnu, men der er sket den Andring, at den frie kulsure Kalk i Tidens Løb, hvor Jorden er sandet og let gennemtrængelig for Vand, er udvasket til saa betydelig Dybde, at den ikke kan naas af Vegetationen, medens kulsur Kalk, der bruser med Saltsyre, paa lerede Jorder ofte endnu træffes i en saadan Dybde, at Planterødder kan naa den.

Men ogsaa Feldspater og andre mere modstandsdygtige Mineraler opløses efterhaanden, og der frigøres derved forskellige Stoffer: Kalk, Magnesia, Kali, Natron, Jærn, Aluminium, Fosforsyre, Kiselsyre m. m., hvoraf flere er uundværlige Plantenæringsstoffer. Eftersom det nedsivende Jordvand er mer eller mindre surt, vil disse Stoffer forholde sig paa forskellig Maade.

Under god Muld, der som oftest kun er ret svagt sur eller neutral $(\mathrm{pH}=5-7)$, vil de af Jordvandet opløste Humusstoffer i Forbindelse med Mineralstofferne afsættes som tynde Hinder omkring Mineralkornene. Disse faar derved et brunligt Overtræk, hvorefter Navnet Brunjord, ogsaa kaldet Sialit efter Indholdet af Kiselsyre og Aluminium (foruden Jærn, Humus og Baseforbindelser). Af Hindernes Evne til at absorbere Fugtighed og Plantenæringsstoffer afhænger i høj Grad Brunjordens Frugtbarhed. Da kulsur Kalk er den vigtigste Faktor til Afdæmpning af Jordbundens Surhed, virker Kalk beskyttende for Brunjord og Muldtilstand, som da ogsaa næsten altid træffes, hvor kulsur Kalk kan paavises i Jordoverfladens Nærhed. 
Hvor Mulden er stærkere sur ( $\mathrm{pH}=4-5$ ), vil Jordvandet kunne opløse de ovenfor omtalte Hinder, saaledes at Mineralkornene optræder blottet for disse og med et hvidligt Skær. Dette viser sig som en »Degradering « af Brunjorden i Form af hvide Sandskorn eller blege Skjolder øverst i denne. Samtidig mister Jorden noget af sin Klumpstruktur og faar Tendens til Enkeltkornstruktur og tættere Lejring.

Det er dog først, naar Jorden er morklædt, at Blegningen bliver saa stærkt udviklet, at der opstaar den Jordbundstype, som kaldes Podsol. I denne er alle Mineralkorn i det øverste Jordlag fuldstændig blottede for Hinder og tillige ætsede (forvitrede) paa Overfladen, saa de har en mat, hvidlig Glans; saakaldet Blegjord eller Blegsand.

De i Blegningshorisonten (A-Horisonten) opløste Bestanddele vil som Regel længere nede, i en Udfældningshorisont (B-Horisonten), udskilles om Mineralkornene, der da bliver omhyllet af brun- eller sortagtige Hinder og mere eller mindre fast sammenkittede. Hvis Udfældningshorisonten er ganske løs og skør, ensartet gullig, brun eller sortebrun og jævnt lysere nedad, kaldes den Rustjord; er den derimod skjoldet, oftest med sorte Aarer og sort foroven og mer eller mindre fast eller haard, kaldes den Al. Rustjorden er formodentlig som oftest en betydelig yngre Dannelse end Alen.

\section{De almindelige Jordbundstyper.}

Muld-Brunjord. Naturlige Former findes her i Landet under Løvskov af Bøg med rig Urteflora, Lystræskov (Eg, AEr, Alm, Ask, Al) med Undervækst af Buske og Urteflora, Krat, eller Overdrev med Græs og Urter. De øverste Par Centimeter af Jorden har løs Klumpstruktur; derunder er Jorden skør, og Klumpstrukturen spores et godt Stykke ned i Overgrunden, som er brunlig eller graabrun, og som for det meste naar en Dybde af 30 til $60 \mathrm{~cm}$ og gaar jævnt over i Undergrunden, der som oftest foroven er noget forvitret og afkalket.

Muld-degraderet Brunjord. Særlig almindelig i Bøgeskove paa lettere Bund og i Egekrattene i Hedeegnene. Noget overfladisk og sur, mørk, ofte lidt sammenhængende Muld eller Overflademuld. Klumpstruktur mindre fremtrædende eller næsten manglende, saa Overgrunden er tæt. Tydelig Blegning i og lige under Muldlaget og ofte et Stykke ned i Overgrunden. Ogsaa i Granskov paa bedre Bund.

Svag Podsolering. Som Regel et tyndt eller løst smuldrende Morlag eller Mor af ret ny Dato. Floraen den for Mor karakteristiske: i Skoven Mosser, bølget Bunke, Majblomst, Liljekonval, Koføde, paa Sletter ung Lynghedevegetation. Under Moren et Blegsandslag fra nogle faa $\mathrm{cm}$ til 1 à $2 \mathrm{dm}$ Tykkelse øverst i Overgrunden, som ikke viser nogen tydelig Udfældningshorisont. Under nydannet Mor kan træffes nogle faa Milli- 
meter til et Par cm Blegsand med en ligeledes ganske ringe, men tydelig Udfældningshorisont. Overgrunden er som oftest tæt og humusfattig.

Middelstærk Podsolering. Almindelig saavel i Skove, navnlig af Bøg og Naaletræ, som i Hede. Under et typisk Morlag findes et veludviklet Blegsandslag (10-20 cm) og derunder Rustjord. Podsolprofilen kan optage hele Overgrunden, eller der kan være en Rest af den oprindelige Overgrund nedenunder Rustjorden.

Stærk Podsolering. Skarpt markeret Blegsandslag over Allag; decideret Hedebundstype. I Blegsandet, som er rent hvidt eller graat, er hyppigt indlejret Humus som et mørkt Lag foroven under Moren og forneden lige over Alen. Denne er som Regel sort foroven, derefter broget kaffebrun, brun og okkerfarvet, og efterhaanden lysere brunlig til gullig nedad.

Den almindelige Hedeal har under c. $5 \mathrm{~cm}(2-8 \mathrm{~cm})$ Morlag c. 20 $25 \mathrm{~cm}$ Blegsand, mørkere øverst og nederst, og c. $25 \mathrm{~cm}$ broget, for det meste temmelig skør Al, hvorunder Jorden et Stykke ned er stærkere rustfarvet end Undergrunden.

Ofte er Alen dog, særlig paa fugtige Steder, kraftigere udviklet og i større Udstrækning sort og haard. (Meget stærk Podsolering). Mærkelige er de saakaldte Altappe, Søjler af haard, sort Al, hyppigt med en Kerne af Blegsand, der strækker sig gennem den brune Al og ned i det rustfarvede Sand eller helt ned i Undergrunden, idet de spidser kegleformet til nedad. Tappene kan være fra et Par Centimeter til flere Decimeter i Tværmaal, og de største breder sig ofte i Undergrunden ud til store vandrette Plader af haard Al. Stedvis træffes over den brune Al et fra nogle Centimeter til flere Decimeter tykt Lag sort, haard Al. Disse svære Alformer træffes meget i Forbindelse med gamle Flyvesandsdannelser, hvor Blegsandslaget paa Grund af paaføget Sand er meget tykt.

Paa fugtige Steder forekommer almindeligt den saakaldte tørveagtige $\mathrm{Al}$, et relativt blødt, humusrigt Lag ovenover den haardere, sorte Al eller over brun Rustjord.

En særlig Al-Podsol er ved Undersøgelserne truffet i det sydøstlige Danmark paa smaa Flader, hvor en næsten lerfin Sandjord (Melsand, Klæg) er overlejret af almindeligt fint Sand. En Profil fra Hannenau Skov paa Falster viste saaledes under Morlaget $20 \mathrm{~cm}$ tæt, graaligt, finkornet Blegsand, $18 \mathrm{~cm}$ mørk kaffebrun, haard Al (Klumper kan knuses med Haanden), 7 cm mørkebrun, meget haard Al (Stykker kan ikke knuses og kun vanskeligt brydes med Haanden) og dernæst tæt, fast, gult Sand til $90 \mathrm{~cm}$. Derunder Melsand af leret Karakter, der førte Grundvand og var blaalig farvet fra $160 \mathrm{~cm}$ og indeholdt kulsur Kalk fra $180 \mathrm{~cm}$ Dybde.

Man kan sige, at Muld-Brunjorden udmærker sig ved, at Humushorisonten strækker sig langt ned i den mineralske Overgrund, under gunstige Forhold helt til dennes Undergrænse, medens man i Mor-Podsolbunden finder 
en Humushorisont lejret ovenpaa den mineralske Overgrund og skarpt adskilt fra denne.

Lokalt paa Kalkklippe, højprocentlig Kalkmoræne, og Kildekalk træffes en basisk, kalkrig Overfladehumus med kalkyndende, meget artsrig Flora. Aarsagen til Typen er dels umiddelbart Kalkens Nærhed, dels Kalkens Evne til at opsuge Regnvandet i sig, saaledes at det atter, naar der sker Fordampning fra Jordoverfladen, stiger tilvejrs mættet med Kalciumkarbonat. Karbonatbevægelsen faar derved Lighed med Foreteelserne i aride Klimater (Renzina, Ruslands Sortjord). Under et ofte mere end decimetertykt Lag Kalkhumus af Regnormestruktur findes et ubetydeligt Lag rustbrun, mineralsk Overgrund over Kalken. Typen findes rundtom paa Kalkgrund, f. Eks. paa Møens Klint.

\section{Jordbundstypernes Fordeling.}

For at forstaa Jordbundstypernes Fordeling indenfor vort Lands Grænser, maa man undersøge Aarsagerne til deres Opstaaen.

Den stærke Udvaskning, der medfører Degradering eller Podsolering af Jorden, betinges af et surt Ovre, resp. sur Muld eller Mor, og en nedadgaaende Vandbevægelse, hvorved de opløste Stoffer kan føres ned i Dybden. Udvaskningen modarbejdes af opadgaaende; kapillar Vandbevægelse til Udligning af Fordampning fra Jordoverfladen og dennes Vegetation, af Transport af Baser som optages af Planternes Rødder med Jordvandet og senere aflejres paa Jordoverfladen sammen med Planteaffaldet, og af Dyrs, i Hovedsagen Regnormes, Transport op til Jordoverfladen af Jord fra dybere Lag.

Jordbundsdannelsen bliver derfor afhængig af Klima, Jordart og Vegetation. Et koldt, vaadt Klima fremmer Mordannelse og giver et stort Overskud af nedsynkende Jordvand. Følgende Værdier for Aarstemperatur og Aarsnedbør viser, at Jyllands Hedeegne alene af klimatiske Grunde er mere udsat for Podsolering end de sydlige Øer:

Aarstemperatur ${ }^{\circ} \mathrm{C}$ Aarsnedbor mm

Jydsk Hedeegn.................. 6.7

700

Laaland ...................... $7.9 \quad 616$

Sandjord er mere udsat for Udvaskning end Lerjord. Ler fastholder nemlig mere af Nedbøren, som da atter fordamper fra Jordoverfladen, end Sandjord, paa hvilken den nedsynkende Vandmængde derfor bliver større. Hertil kommer, at Lerjordens større Forvitrings- og Absorptionsoverflade modvirker Podsoleringen. Kalkens basiske Virkning modarbejder Podsoleringen; den er som Regel stærkt udvasket paa Sandjorderne, medens vore Lerjorder ofte er kalkrige i nogen Dybde. 
Mordannelse er betinget af Plantevækstens Art, men fremmes tillige af koldt Klima og Basemangel. Mordannende er især Lynghede, Skovfyr med Bundflora af Blaabær og Tyttebær, Rødgranskov og i noget mindre Grad Bøgeskov. Da Mordannelse vist i Almindelighed kan betragtes som en Forudsætning for Podsolering, er Jordbundstilstanden afhængig af Vegetationen, ikke blot af Nutidens men ogsaa af Fortidens Vegetation helt tilbage til Istidens Ophør. Plantevæksten er ikke alene betinget af Klima og Jordbund, men ogsaa af Historien. Menneskers og Husdyrs Ødelæggelse af Skovene har over store Strækninger været Aarsagen til Hededannelse og har dermed fremmet Jordens Podsolering.

Podsoleringen har udviklet sig efter den sidste Istid, men om Podsolens Alder er det iøvrigt meget vanskeligt at dømme. Der har været fremført, at Hedesletternes Podsol skulde kunne føres helt tilbage til en Tundra samtidig med Isens Afsmeltning (P. E. MüLLER). Herimod taler, at Aarets Middeltemperatur i Afsmeltningstiden sandsynligvis har ligget over $0^{\circ} \mathrm{C}$, saaledes at Jorden ikke har været bundfrossen, og den karakteristiske cirkulerende Bevægelse af Jordlagene, som menes at have fundet Sted paa Bakkeøerne, spores ikke paa Hedesletterne, hvis Sandlag ligger i uforstyrrede vandrette Lag, saaledes som de er afsat af Smeltevandet. Endvidere maa Hedesandet lige efter Aflejringen have indeholdt en hel Del Kalk; Rester af afkalket Bryozokalk i Form af bløde Kiselknolde findes udbredt og ofte i ret stor Mængde i Hedesandet, og et saadant Kalkindhold, der næppe blev fuldstændig opløst, før en højere Temperatur indfandt sig, har modvirket Mor og Podsoldannelse.

Det er vel tænkeligt, at store Dele af Hedesletterne altid har haft en Art Hedeflora, hvori dog Bævreasp, Birk og senere Skovfyr maa formodes at være indvandret, men Pollenundersøgelser af Moserne viser, at Lyngheden først fik stor Udbredelse i Jærnalderens kolde og fugtige Klima. At Hedepodsolen kan gaa længere tilbage end Broncealderen, ja ind i Stenalderen, viser Fund af Podsolprofiler under Kæmpehøjene. De lettere Podsoldannelser paa Hederne i Skovegnene er formodentlig i det væsentlige først opstaaet efter Skovenes Ødelæggelse.

Det øverste Jordlag, der udgør Hedernes Blegsandslag, er for det meste stenfrit og af en ret ensartet Mægtighed, mellem $20 \mathrm{og} 30 \mathrm{~cm}$. Dette tyder paa at der er foregaaet en Nedsynkning af Stenene i Lighed med den, der ved Regnormenes Hjælp foregaar paa Muldbunden. Som Aarsag kan lettest tænkes en oprindelig Muldjords Regnormefauna, men maaske ogsaa Myrer, Gravehvepse og andre gravende Dyr, der kan trives i Lynghede.

Fordelingen af vestjydske Bakkeøer, ekstramarginale Sandsletter, Diluvialsand og Lerjorder foraarsager i Forbindelse med Vestjyllands humide Klima, at der kan drages to Hoved-Jordbundsgrænser igennem Jylland, af hvilke den ene i sin nordlige og midterste Del falder sammen med 
Kort over de større Podsolomraaders

Udbredelse i Danmark.

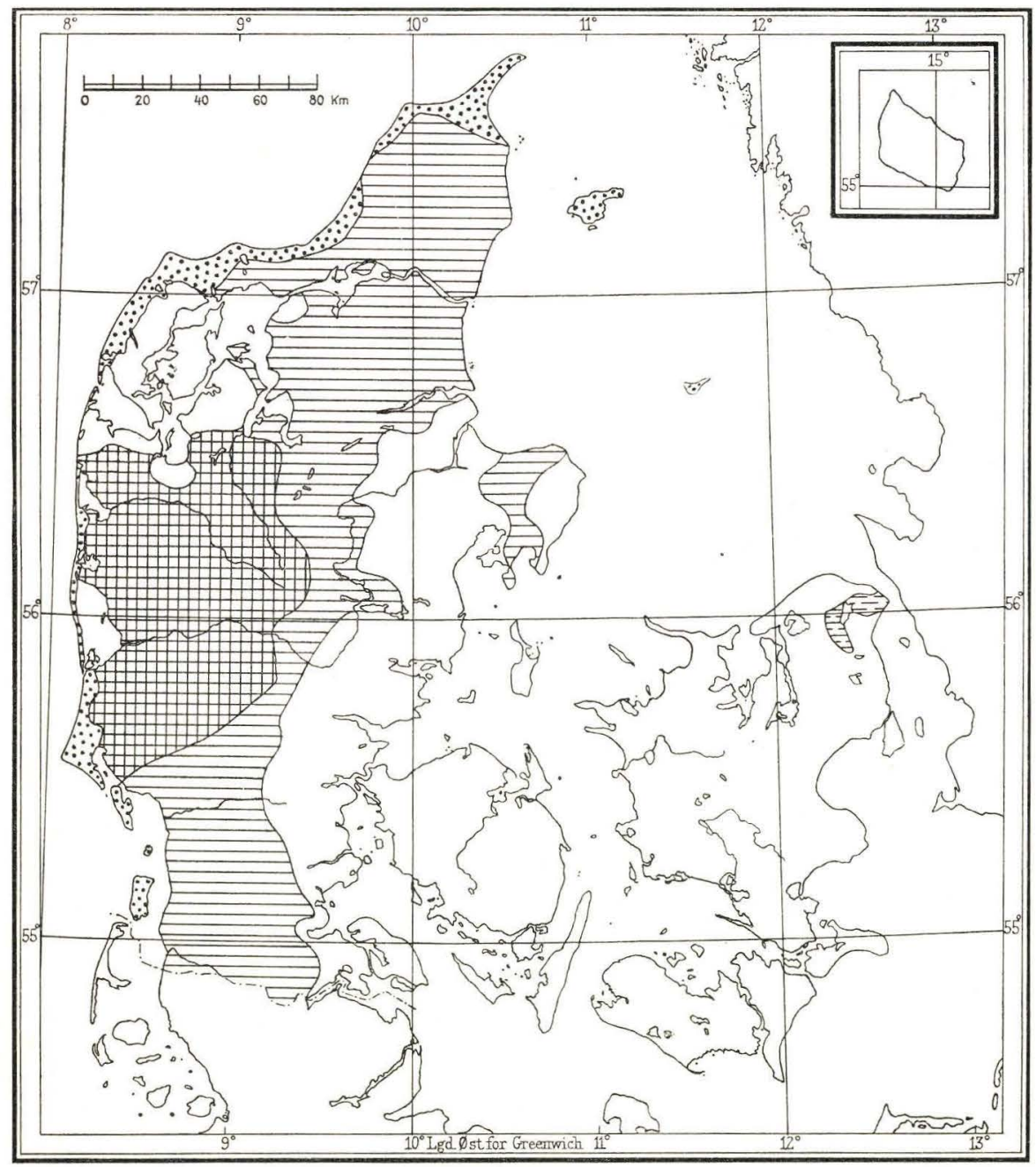

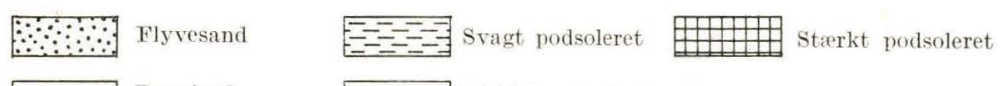


Israndslinien fra den sidste Istid. Disse Grænser og enkelte andre Hovedtræk i Podsoltypernes Fordeling fremgaar i grove Træk af det lille Kort paa Side 31 .

Landet foran Isranden er i Hovedsagen stærkt podsoleret. Dette gælder navnlig Hedesletterne, medens store Dele af Bakkeøerne samt Erosionsdalenes Skraaninger kun er middelstærkt podsolere. Jordbundstilstanden bliver mildere sydpaa, og den stærke Podsolering er mindre fremtrædende i Sønderjylland end længere mod Nord f. Eks. paa Karup Hedeslette. Paa gamle Sandflugtsarealer kan træffes særlig stærk Podsolering. De udstrakte Flyvesandsarealer langs Vesterhavet er derimod gennemgaaende saa unge, at Podsoleringen kun er lidet fremskreden og ofte kun svag eller næppe synlig. Paa de lerede Dele af Bakkeøerne kan træffes udprægede Brunjordsprofiler.

Det sandede og i Hovedsagen stærkt kuperede midterste Strøg af Jylland omfatter, hvor der findes naturlig Vegetation i Form af Skov og Hede, i Hovedsagen middelstærkt til svagt podsolerede Jorder. Mod Nord omfatter dette Bælte Jylland Øst for de lerede, kalkrige Jorder omkring Limfjordens vestlige Del og ud til Kattegat omtrent ned til Randers Fjord. Her bøjer Podsolomraadet bort fra Kysten, og videre mod Syd danner Østjylland sammen med de danske Øer et stort sammenhængende Brunjordsomraade, hvori der dog findes adskillige større og mindre Podsolomraader. I Sønderjylland gaar det middelstærkt podsolerede Omraade ud til Marsken, men er dog paa flere Steder afbrudt af Partier med stærk Podsolering. I det midtjydske Podsolomraade kendetegnes Hederne, der for det meste tidligere har været Skove, ved middelstærk Podsolering med Rustjordshorisont; kun hvor der er Sandsletter i Floddale og foran senere Israndslinier eller gamle Indsande, kan stærk Podsolering træffes. I Skovene er middelstærk til svag Podsolering almindelig, men store Skovarealer har Muldbund med Brunjord, som dog for det meste er tydelig degraderet. Det samme gælder Krattene, der træffes saavel i Midt- som Vestjylland, og i hvilke Jorden som oftest er stærkt degraderet, og derfor ved Krattenes Ødelæggelse og Overgang til Hede let gaar over til Podsol.

Et større, isoleret, middelstærkt Podsolomraade findes i Djursland, medens tilsvarende sandede Omraader paa Øerne næppe kan betegnes saaledes, idet middelstærk Podsolering vel forekommer, men Hovedtypen er dog svag Podsolering og degraderet Brunjord. Grunden er den, at udpræget Lynghede ikke er almindelig, og Podsolen forekommer mest i Bøgeskove og paa Overdrev, hvor Lyng vel findes, men, maaske som Følge af det mildere Klima, ikke er saa stærkt dominerende i Floraen og mordannende som paa de jydske Heder. Af større degraderede til svagt podsolerede Omraader paa Øerne kan nævnes Egnen omkring Esrom Sø, Dele af »de fynske Alper«, det sandede Omraade, der gaar over Bromme Skov ud imod Saltbæk Vig, og Mogenstrupaas-Egnen. 
Lokalt, indenfor smaa Arealer, kan Podsol træffes rundt om. Svag til middelstærk Podsolering er almindelig i vore Bøgeskove paa sandet eller let leret og kalkfattig Jord, navnlig hvor Bunden er blevet morklædt, fordi den har været udsat for Træk.

Den omtalte meget haarde Al paa Melsand er truffet ved Ullerup paa Fyn, Knudskov i Sydsjælland, Hannenau paa Falster og Fyrvænget paa Laaland.

Bortset herfra danner Øerne og Østjylland et stort, samlet Brunsjordsomraade, hvor Degradering dog, i alt Fald i Bøgeskove og Granskove, er et hyppigt optrædende Fænomen. Et særligt, isoleret Brunjordsomraade findes paa de kalkrige Lerjorder om den vestlige Del af Limfjorden. Ogsaa Bornholm er i Hovedsagen Brunjord; paa de store lyngklædte Arealer i Øens høje Indre findes en Del Podsol, men - formodentlig som Følge af Morænens særlige Karakter — er Podsoleringen kun svag til middelstærk.

Gennem Kulturindgreb kan der ske Forandringer i Jordbundens Karakter. Alene ved den Forandring, som der i Skovdriften sker med Lokalklimaet og med Plantearterne i Bevoksning og Bundvegetation, kan Muld forandres til Mor og omvendt. Hvor man finder Mor paa Brunjord eller Muld over Podsol, kan man gaa ud fra, at Overgrundstypen skyldes en anden Husmustype end den nuværende. Denne Uoverensstemmelse mellem Humus- og Overgrundstype træffes f. Eks. almindeligt i Gribskovs Bøgebevoksninger. Ligeledes kan man træffe Egekrat med Muldflora over Podsol, tydende paa, at Arealet, i alt Fald midlertidigt, har været lyngbevokset.

Langt mere gennemgribende ændres Jorden af Agerbruget. Gennem Bearbejdning, Tilførsel af Mergel og Gødning, og Indførelsen af et nyt Plantedække opnaar den podsolerede Hede efterhaanden mere og mere Brunjordskarakter, selv om Blegsandet ofte i en lang Aarrække kan skelnes paa Agrene. Særlig hurtigt sker Andringen ved dyb Bearbejdning og Pulverisering, hvorunder de i Alen udfældede Kolloider bringes op i Pløjelaget, og man straks mekanisk - i grove Træk — retablerer den Fordeling af Kolloiderne, som kendetegner Brunjorden. Hvor Bearbejdningen ikke er naaet ned, vil den oprindelige Jordbundstype meget længe kunne genkendes. Medens en Retablering af Muldtilstanden ofte vil være mulig indenfor en kort Aarrække alene ved Forbedring af Lokalklimaet og en Andring i Plantedækket, saa vil der til en Omdannelse af Podsol til Brunjord, hvis den overhovedet er mulig uden Dybbearbejdning, behøves Aarhundreder. 


\section{The Surface Deposits of Denmark.}

Q uartary deposits of different kinds occur so to speak everywhere in the surface of Denmark. Having its origin from such earths, the soil has nowhere been formed directly by the decomposition of prequartary rocks in situ. The thickness of the Danish Quartary is on an average about 50 metres, but it may reach as much as 200 metres. The shape of the country bears most distinctly the impress of the course of the Ice Age, and an account of the soil of Denmark means the same as a review of its Quartary deposits.

Nevertheless the substrata underlying the Quartary also have some influence on the forms of the surface on account their levels, especially where tectonic movements have played a part, for instance where horsts or fissure valleys occur, or where the rocky ground crops out on the island of Bornholm.

Overlying the pleistocene deposits are the late-glacial deposits from the period when the last ice-sheet was melting away, and the postglacial deposits from the following time, when vegetation had spread over the country up to the present day. These deposits, besides being separated according to age, are also classified according to their place of deposition, viz. into marine deposits and fresh-water deposits. Both groups again contain different kinds of deposits, for besides seabed deposits proper, the marine deposits also comprise marsh, whilst the fresh-water deposits may be divided into the purely organogenous peat deposits and the other fresh-water deposits such as mud, clay, sand, as well as calcareous tufa and lake marl. The eolian deposits consist of blown sand, which may be both late-glacial and post-glacial and occurs both along the coasts, mostly in dunes, and in inland sands.

Denmark's surface is a mosaic of Quartary deposits, overlying the strata that are earlier than the Quartary period. The three great main groups of the glacial deposits: clay, diluvial sand and heath sand, form the basis of the mosaic itself, and the younger deposits, which present a rich variation, form innumerable small areas which break the broad outlines in the distribution of the said three main groups of glacial deposits proper. 
Disregarding all the younger deposits and confining ourselves to the three typical glacial deposits: clay, diluvial sand and heath sand, we quickly discover that a line running from Bovbjærg SW of Lemvig roughly on to Dollerup, SW of Viborg, and from there southwards through the entire peninsula of Jutland, divides Jutland into two parts, and that these two parts differ essentially. South and west of the line there is mostly sand; within this area the heath sand has its main distribution, and in the spaces between the outwash plains it is diluvial sand that predominates. North, and especially east of the line there is mostly clay, sand being only secondary in importance; and where there is sand, heath sand plays a very subordinate part. This dividing line, which appears very distinctly on the map, was drawn by the inland ice during the last glaciation, as throughout a great part of that period the margin of the ice was situated along it; it is called the main stationary line of the inland ice.

The landscape in West Jutland which in the last glacial period lay beyond the inland ice and, on account of the arctic climate, had no covering of vegetation, was so evened out by precipitation and solifluction that the original forms of terrain were effaced. Depressions without an outlet were filled up or converted into valleys, and hill tops and ridges became lower and flatter. Extensive outwash plains were spread over the large lower parts of West Jutland, the melt-waters from the inland ice building them up gradually by silting the heath sand out over them. The outwash plains fall slightly towards the west, and their size and regularity bear witness of the long time it took to to form them.

In East Denmark and North and East Jutland the landscape is not flattened out in the same manner as in West Jutland. The slopes are much steeper and the surface forms vary much more. There are uncountable small depressions without an outlet and a constant variation of wide flat-land and hilly ground. The valleys are much deeper and the hills much higher; valleys with long lakes and chains of lakes are especially characteristic of East and North Jutland. In a few words, the main difference is that in West Jutland the landscape has grown old, whereas east and north of the main stationary line the land covered by the ice during the last glaciation has retained its youthful forms.

Since the glacial periods considerable alterations have taken place here and there in the outlines of the country, notably caused by changes in the levels; on the whole, however, the general development has been that in a great many but sharply delimited areas there has been a quiet process of deposition with the aid of wind or water. In the post-glacial fresh-water deposits vegetation has played an especially great role. 
After this introductory survey of some of the principal features in the moulding of Denmark's surface in the Quartary period we shall examine the significance and use of the various terms on the accompanying map.

\section{Till and Clay.}

The term clay comprises most of the clays occurring in the surface of Denmark, as it includes first and foremost moraine clay (boulder till) and diluvial clay, and in addition also late-glacial freshwater clay. The most important of the clays not included in this group are the late-glacial marine clay, Yoldia Clay, in Vendsyssel, and the marsh, which occurs along the southern part of Jutland's west coast.

Moraine clay or moraine marl is the commonest of Danish clays. It is the material carried along by the inland ice from the regions over which it passed in Scandinavia, deposited unassorted and in the same mixture as when it was contained in the ice. Through mixing with chalk in the substratum it has acquired a lime content that varies between 10 and 30 per cent.

Its importance to the country may be visualized by an examination of the village names on the map; for it is very characteristic that the density of villages generally is greatest in the very areas where moraine clay occurs. This means simply that moraine clay is a condition of fertility to such a degree that it is reflected in the density of the population, disregarding, of course, the towns, which in many cases owe their existence to other circumstances.

The main distribution of the moraine clay coincides very well with the area covered by the inland ice during the last glaciation. However, this does not mean that moraine clay does not occur in West Jutland, but there we mostly find it in scattered spots, more rarely in large, continuous areas as in East Denmark. In West Jutland, especially in Sønderjylland, moraine clay is sometimes found at a depth of about I metre, covered by the so-called "stony sand" (see page 44). On the surface the soil may look rather meagre, and yet it shows the effects of the water-stopping stratum just below; this especially is of importance to tree growth, but to some extent it also affects agriculture.

But the main area of occurrence of the moraine clay is to the north and east of the main stationary line. In the districts round about the westerly part of Limfjord there are wide tracts with moraine clay, deposits from the northern ice-sheet which in the last glacial period covered the country up to the line between Dollerup and the North Sea. There is scarcely any moraine clay in the surface deposits of the 
hill-country of Vendsyssel, but some diluvial clay. Moraine clay is also rare in the west part of Himmerland, whereas in East Himmerland there is some along the west side of Lille Vildmose. A belt of moraine clay runs from the mouth of Mariager Fjord to Randers. The northern half of Djursland is very meagre, but from a line almost from Grenaa through Randers to Viborg begins the great continuous belt of moraine clay which follows the east coast of Jutland right down to the Danish-German border.

The Danish islands consist mostly of moraine clay, only scattered areas having a stronger stamp of diluvial sand; this applies to Southwest Funen and Northeast Sealand. On Laaland-Falster is found some of the greasiest moraine clay of the country; on Laaland especially it forms extensive moraine-flats. On Bornholm it occurs as a continuous ring round the diluvial sand in the interior of the island.

Most parts of the moraine clay region in Denmark are characterised by wide, quiet forms of landscape. The most outstanding form is the moraine-flat, which occurs commonly both on the islands and in Jutland. To take a single example there is the district called The Heath (Heden) between Copenhagen, Hedehusene and Køge:

"Consisting almost exclusively of moraine clay, the moraine-flat is characterised by its very slightly undulating surface, looking as if it were smoothed out or planed. Conceivably the smoothing-out was caused by the ice-sheet, which, depositing its moraine material, was moving slowly forward, at any rate until the thickness of the ice was so slight that any further deposition of material when the ice stood still could not alter the surface form and produce the uneven character that stamps a landscape which has been formed under stationary ice" (V. Mrlthers 1922).

One may add to this that evaporation must have played a great part in the disappearance of the ice, as the moraine surface bears not a trace of channels for the melt-water which a normal melting would have produced. Where in the final period the ice-sheet left large patches of dead ice behind it, we find more uneven surfaces. The form of landscape which is named a moraine-flat must therefore have been caused by the ice having been in motion until it became so thin that evaporation was sufficient to make it disappear. The best explanation of the great expanse of the moraine-flat landscape is a dry and relatively mild climate with its devastating effects upon the ice while it was still in motion.

Very often moraine clay is also associated with hummocky landscape; there are frequent stretches of it in the moraine-clay regions, though it is not nearly so frequent in occurrence as the moraine-flat landscape. It has most probably formed under stationary ice, where 
the moraine material in the ice has been very unevenly distributed. Various hypotheses have been advanced at different times as to how this landscape came about, some of them based upon direct observations, others very theoretical in character. For the purpose of providing some idea of how different they are the following examples are given.

N. V. Ussing (1907) has shown that the hummocky landscape south of Lemvig and on towards the east as far as the district north of Alheden must be due to the melting of buried lumps of ice. The extreme southern boundary of this landscape corresponds to the main stationary line of the inland ice; on the north it is bordered by a moraine line caused by a revival of the activity of the northern ice-sheet behind the dead marginal zone. If this area had not been covered with ice, the meltwater from the ice of the marginal moraine behind the hummocky landscape would have smoothed it out; but as it actually is very uneven, Ussing concludes that this hummocky ground must have been formed after the ice-sheet had waned, caused by the shrinking of lumps of ice which were buried by the material deposited in front of the rearmost of the two ice margins.

K. GRIPP (1929) on Spitzbergen has observed intersecting systems of clay walls left after the ice-sheet had disappeared. They formed veritable impressions of the fissures in the underside of the ice which had become filled up from below with bottom moraine under the pressure of the ice on its substratum. In those cases where this bottom material consisted of sand, the walls collapsed so much during the melting process that they were only faintly observable on the landscape, whereas when the material was clay they left small eminences, giving the terrain a hummocky appearance. According to GrIPP these systems of fissurefill are formed at some distance inside the ice margin in the form of a belt conformable to it; still further behind the hummocky landscape the moraine-flat is formed under that part of the ice where the fissures are closed.

Poul Harder (1908), writing about the Aarhus region, assumes that the hummocky landscape there is formed in the marginal zone of the ice, where its thickness has been slight and its movement so weak that the ice has been unable to smooth out the unevennesses in the bottom moraine. V. Milthers (1922) considers it necessary to assume that the ice was stationary while the hummocky landscape was being formed. Victor Madsen (1928) likewise presumes that the ice-sheet was stationary; the depressions have come into existence where the ice masses held out longest, the hummocks where the moraine material accumulated between the ice masses.

The hummocky landscape is not confined to the moraine clay alone; it also occurs in more meagre regions, sometimes with alternating sand 
and clay; moraine-flats, on the other hand, can only come into existence in genetic connection with moraine clay.

Stoneless glacial clay, diluvial clay, is often associated with depressions in the surface, but this is not the invariable rule by any means. It is often found under apparently casual conditions of deposition over large and small areas, extending right up to the surface or at slight depths. In only few parts of the country does it occur in any wide expanse; but in southwest Jutland over a large area it is the commonest clay. This area has been thoroughly described by Axel Jessen (1922). He has shown that in Southwest Jutland the diluvial clay must have been deposited in the early part of an interglacial period during the melting of a waning ice-sheet, in front of and close up to the margin of the ice. Later on the diluvial clay has been transgressed by an advancing new inland ice, which in some cases has disturbed the stratification and often has covered it with sand, gravel or moraine clay. Sometimes in this area the diluvial clay occurs out on the outwash plains, where it has either been covered with heath sand or it may have been exposed by meltwater erosion, so that it is on a level with the outwash plain and thus is a planed-off hill island. The hill islands in Southwest Jutland dating from the penultimate glacial period, and this diluvial clay being an interglacial period older than the surface layer of the hill islands, it must have been deposited in the beginning of the penultimate interglacial period and therefore belongs to the end of the same glacial period as the moraine under the Esbjerg Yoldia clay. This means that it dates from the earliest of the two interglacial periods known in this country.

In many parts of the country there are other forms of diluvial clay; one special variety is the so-called ice-lake clay or "Plateau clay" (Fladbakkeler), which has been deposited in lakes the bottoms of which were formed of the country's natural surface, but whose sides have more or less consisted of ice. In some places only the outlet of a natural depression has been blocked by the ice; in other places the ice-lakes on most sides have been surrounded by the ice itself, so that when the ice disappeared the bed of the lake remained as a more or less high plateau, or sometimes as a shelf resting against a still higher hill. For instance, in an area between Odense, Middelfart and Assens there are numbers of large, flat shelves, of which the horizontal surface consists of greasy diluvial clay, used widely by the many brickworks in the district. See V. MiLthers (1931).

There are numbers of plateau hills in various districts of North Sealand; they are particularly common between Farum and Lillerød. V. Milthers (1935).

At Egernsund (near Graasten) there is a very considerable deposit 
of ice-lake clay, especially along the south side of Nybøl Nor, which has been filled up and closed by ice. This ice-lake was examined by Sigurd Hansen.

At Stenstrup in Funen there also occur deposits from a large ice-lake. The sides were mostly formed of natural barriers, but on the north and the southwest the terrain in its present form cannot have been a barrier to the water; at these places there must have been barriers of ice while the lake existed and while the clay was being deposited. The deposition of clay in Stenstrup lake has continued right up into late-glacial times, for there are plant-bearing beds, gyttja, from the warm Allerød phase in the late-glacial period (VICTOR Madsen (1903 and V. Nordmann (1922)).

In several of these ice-lakes and clay plateaux an examination has been made of the annual strata, the varves, for the purpose of following their mutual relations and chronology. In this country, however, it has not been possible to find a continuous varve scale, owing to the fact that our diluvial clay deposits occur in small, restricted basins which do not permit of comparison with one another on any large scale, as they each comprise annual varves from only a very brief term of years.

As a general rule, the diluvial clay is more calcareous than moraine clay. Whereas the lime content of the latter lies between 10 and 30 per cent., the content of the diluvial clay usually is between 20 and 50 per cent. Diluvial clay is used much more extensively for marling than moraine clay, as it often has such a high lime percentage that it pays to utilise it in that manner.

Being practically free of stones, diluvial clay is often very suitable for brick-making and in fact is in wide use for building-bricks. Almost wherever there is diluvial clay in this country there is a brisk brickmaking industry in the neighbourhood.

Late-glacial freshwater clay is also comprised under the term clay on the map. It occurs in various parts of the country in natural depressions in the surface, but comparatively is not nearly so frequent as the two clays described above. It occurs as independent deposits and also as the continuation of glacial meltwater deposits, for instance at Stenstrup lake; more often, however, we find it as the bottom layer in postglacial bogs. It often contains remains of arctic plants, for instance Dryas octopetala, from which it is called Dryas clay. Its distribution is not particularly wide, which is a natural consequence of its being limited to the local surface depressions. It did not originate from the meltwater of the ice, but from the streams which drained the rainwater and snow-water from the surface of late-glacial landscape which, though ice-free, did not bear much vegetation. It does not differ much from diluvial clay and is utilised in the same manner. 
A matter of great importance in the burning of the clays occurring in the surface of Denmark is their degree of weathering. Down to a depth of 1 to 2 metres (sometimes 3 to 4 ) the clay is usually oxydised and freed of its lime content. The oxydisation of the iron compounds colours the clay yellowish or reddish, which is then called red clay; when burnt it gives red bricks in contrast to the deeper, unweathered blue clay, which makes yellow bricks. The technical use of Danish clays is described by Johannes Andersen in "Summary of the Geology of Denmark" (1928).

On the map the three clays: moraine, diluvial and late-glacial freshwater clay are put together under the name of clay. The other clays found in this country have not been included in the group, for various reasons, but it is only natural to refer to them here.

The term clay on the map does not comprise:

Late-glacial marine clay, mostly found in Vendsyssel; on the map it is not separated out from the other late-glacial marine deposits.

Post-glacial freshwater clay, usually occurring in association with sand, mud, gyttja and other alluvial deposits, comprised on the map under the term "meadow-land".

Post-glacial marine clay, which in Denmark occurs almost exclusively in the form of marsh, is shown separately on the map. However, there is also post-glacial marine clay in some of the areas which have been artificially reclaimed by enclosing and pumping dry; these areas are included in the regions marked off as post-glacial marine deposits.

There are many other kinds of clay in Denmark, also utilised to a great extent; but, as they occur only exceptionally and casually in the surface, they are not indicated on the map. Sometimes they are to be seen in the cliffs, but usually one has to bore in order to get to them. Often they lie so close to the surface that they can be dug in open pits, in which cases they are used for earthenware of various kinds. The most common are the Tertiary clays in Jutland, which have a wide distribution. The finest potter's clay is had from the Bornholm Rhætic-Liassic beds. As stated, none of these older clay beds are at the surface and therefore they are not included in the map in the group shown as clays. They will be found on J.P. J. RavN's Underground Map (1922).

\section{Diluvial Sand.}

On the map the term Diluvial Sand comprises both sand and diluvial gravel; it also includes moraine sand and moraine gravel, but is not applied to stratified sand and gravel deposited before the edge of the 
last inland ice in basins or in the form of outwash plains, these deposits being now generally called heath sand.

Diluvial sand is the most widely distributed type of sand in this country. The grain varies much in size owing to the fact that it was deposited in running water very closely associated with the ice-sheet. There is no distinct boundary between diluvial sand and diluvial gravel, which here and there may be very coarse. From the profiles it can be seen that the stratification of the sand has changed incessantly during the course of deposition. False bedding is often seen, and the strata often have a marked dip, and they are pronouncedly unconformable. Within the individual sand beds the strata are mostly parallel, and therefore the structure is called parallel-discordant. The force of the stream has likewise varied constantly, which explains why the grains vary so much in size. Beds of fine, stoneless sand are often overlain by stony gravel, which again may be overlain by finer sand. The variation is not at all regular, except that the material is always watersorted. Usually it has been completely cleansed of clay material, due to the lively movement of the water during deposition.

Very often there is a fault in the strata, which have either been exposed to pressure after their deposition, the result of moving ice, or they have been deposited over buried ice fragments which, through their melting, have caused the sand strata to settle.

The river beds that carried the glaciofluvial waters have often changed their direction, the melting of the ice having caused constant alterations in the flow. The result is that the sand can be seen to be bedded without any connection with the present surface of the terrain, so that it is impossible to see what direction the rivers have taken. Sometimes the sand lies quite irregularly over large areas and apparently accidentally. In fact, diluvial sand occurs most frequently in very hilly districts. It is particularly common in marginal moraine areas together with diluvial gravel, moraine sand and moraine gravel, which, as stated above, are not shown separately on the map.

Actually, moraine sand and moraine gravel are not particularly common; in marginal moraine areas, however, they are typical and widespread. They are unstratified and contain unsorted stones and grain-sizes from the coarsest to the finest. Sometimes one finds the socalled boulder-packs with enormous quantities of stones in association with the marginal moraines.

A consideration of the map will show that along some of the more important ice-edge lines there is diluvial sand in especially large quantities within areas which otherwise are mostly characterised by moraine clay. In such cases the sand occurs in the form of a belt along the iceedge line itself, and behind that zone follows the moraine clay. On the 
map this is especially prominent in three different places: Behind the great main stationary line of the last glaciation from Dollerup to the south; along the East Jutland ice-edge line in a curve round about the bay at Aarhus; and finally, in a curve round Køge Bay, conforming to the position of the ice-edge there.

Diluvial sand is also connected with a special area which, as a landscape, belongs to the moraine clay regions, viz. the elongated and very narrow ridges, the eskers, which occur in East Denmark within the region of the last inland ice. They are often very prominent in the landscape when, as is usually the case, they are surrounded by even ground with clayey soil. They always attract great attention by their sharp ridge and sandy or gravelly composition. They have come into existence in direct contact with the ice, as a rule in river beds in channels in the ice. The manner in which these eskers were formed differs greatly, by the way, and all endeavours to generalise a single explanation have so far stranded upon the rich variety in their structure.

The direction of these eskers is often parallel with the direction of the ice drift in the particular region, in which case they represent the great meltwater rivers of the ice-sheet. Sometimes, in continuation of the eskers, it is possible to see parts of the river course where under the ice it has cut down into the substratum and formed deep, elongated and irregular valleys, the so-called tunnel valleys. The finest specimens of these valleys occur in East Jutland, where now in part they form the East Jutland fjords and in part most of the valleys and chains of lakes which continue westwards from the fjord valleys in towards the main stationary line of the ice; they open out there in the outwash plains, which are built up of deposits from the meltwater rivers of the tunnel valleys outside the ice-edge.

On the islands the eskers occur just as frequently as the tunnel valleys; we often find them both combined along the same subglacial river beds. On the map some of the largest eskers are prominent, because they are of such a size that their sand deposits could be shown as independent regions. In Sealand one observes Mogenstrup Esker (near Næstved) and Køge Esker.

Only the fewest Danish eskers could be included on the map, however, as their area, especially as to width, is so slight that they could not be plotted without distorting the picture. Furthermore, in many cases they do not differ from the material forming the surrounding land, as there is also sand in these areas; or, as for instance is the case with Sallinge Esker in Funen, the esker in many places is covered with a mantle of moraine clay, so that on the map it cannot be separated from its surroundings.

Sand, gravel and stones are employed for concrete and mortar mix- 
ing, and for road-making and water filters. Special types of sand are used for moulding in the foundries.

Within a single region, diluvial sand is most commonly distributed in Himmerland, where it predominates as the principal surface material. Apart from East Himmerland, clayey soil is very rare in that county. In Vendsyssel the high ground consists almost exclusively of sand.

In West Jutland sand is widely distributed; to a very great extent it is diluvial sand, but in that part of the country we often find a form that is called Stony Sand; it is unstratified and contains hardly any lime. There are various theories as to its origin; one opinion is that it is a surface moraine which, while on the surface of the ice, has been well washed out, the lime and clay being removed by the agency of both water and wind (VICTOR MADSEN 1928); another theory is that it is the result of a weathering process, whereby the surface layer has been decalcified and, by means of the percolating water, freed of its clay (A. Rosenkrantz 1933). But there is a third possibility, viz. that this surface layer (which in West Jutland, where it has its main distribution, has after its deposition gone through an entire glacial period (besides two non-glacial periods) and therefore has long been exposed to an arctic climate which, in the first place, has prevented any growth of vegetation and, in the second place, has promoted arctic conditions in the earth's crust) must have obtained its peculiar character as a consequence of the so-called "Brodelbewegung" whereby the uppermost layer of the earth has been agitated into a kind of "boiling" motion. While this motion was going on one can quite well conceive that the various parts of the soil have been freed of their clay content gradually as they rose to the surface, and that their lime has been washed out while simultaneously the stones were exposed to the grinding of the blown sand and have acquired the sand-polished form which is peculiar to the stones of the Stony Sand.

\section{Outwash Plains.}

The material in the outwash plains, in Denmark called heath sand, is often given the unsuitable name of late-glacial sand; this must not be taken to mean that heath sand dates solely from the late-glacial period, for it was mostly deposited in the most pronouncedly glacial phase of the last glacial period, being the extramarginal deposits of the meltwater rivers. The expression "late-glacial" sand must therefore be interpreted as: extramarginal sand.

The meltwater rivers laid down their material in two different forms, which were governed by the drainage conditions, the quantity of mat- 
erial, the force of the flow and perhaps especially by the duration of the deposition. The two forms in which the extramarginal deposits occur are outwash plains and extramarginal river-valley terraces.

Outwash plains have originated as large sand deposits which have been deposited in front of the inland ice by the meltwater rivers in the same manner as those from glaciers, for instance in Iceland, to this day deposit sand and gravel in the form of large plains in front of their margin. The sand has been deposited on the surface of the country, filling up depressions and reforming the landscape, so that now it appears as large, extensive plains which are almost horizontal. These are built up of very flat cones, the apices of which occur where the meltwater rivers issued from the inland ice, and they have a very slight dip, about 1: 500, which is extremely little. Therefore they look as if they actually are horizontal, and, on account of their size, and because they often are heather-grown, they have early attracted attention as a peculiar landscape, one that is especially characteristic of West Jutland.

The soil has been washed out well by the glacial rivers, and therefore percolating rain water later on would have an easy task in continuing the process; as a consequence, the resulting hardpan has in early times discouraged much cultivation of the heath. The outwash plains proper are therefore not so densely populated, as indeed appears from the map, there being much fewer village names on the heaths than in the clayey regions; and there are also many more village names wherever the soil consists of diluvial sand instead of heath sand.

The stratification of the heath sand is almost horizontal, following the smooth surface which, as stated, has an extremely slight dip. There is not the same discomposure in the stratification as in diluvial sand; the explanation is that the deposition of the heath sand has proceeded quite tranquilly. The stratification of heath sand is described as horizontal and conformable.

The grains of heath sand are more uniform in size than those of diluvial sand, for the reason that the water-sorting by the rivers that have streamed out over the outwash plains has been much more thorough. We find especially two predominant sizes: the ordinary sand grain which has been transported in a state of suspension in the water to the place where it has sunk to the bottom, and the small flat stones carried by the bottom current in the meltwater rivers, rolling along the bed to the place where they now occur. I. A. UdDen (1914) has shown with regard to rivers that there is a constant size-ratio of $16: 1$ between the stones rolled along the bottom by a stream of water and the grains that are kept in suspension, but which are on the border of being precipitated, by the same stream. This has not been investigated as far as the Danish heath sand is concerned, but there seems 
to be a similar constant ratio between the two predominant sizes, and therefore it is a reasonable assumption that the cause is the same.

The other group of heath sand deposits is the extramarginal river-valley terraces, which contain the same material as the outwash plains. Along almost all the larger Danish streams there are these terraces, bearing witness that the valley was formed by meltwater in the glacial period. This applies both to those that were cut down into the outwash plains during the last phase of their formation, and to the larger river valleys in the rest of Denmark. The most important of the rivers that represent the final phases in the deposition of the outwash plains are Skive Aa, Storaa, Skjern Aa with its tributaries Brande Aa and Omme Aa, and Hvidaa. The independent, extramarginal valleys include for instance the Kongeaa valley, representing a genuine outwash plain but, on account of its elongated form, more resembling a river valley.

During the waning of the ice from the region south of Limfjord there has been a series of phases with drainage valleys along various directions, gradually as the ice permitted water from the easterly ice-sheet to find an outlet in other directions than out over Karup outwash plain (N. V. Ussinc 1903, 1904, 1907, and Keld Milthers 1935). As long as the margin of the inland ice lay along the main stationary line, the meltwater was able to move westwards over the main Jutland watershed; but when the ice withdrew from that line the rivers were unable to pass over it, and that is why the changes in the drainage became so marked. When the ice yielded in the region north of Alheden, the meltwater made its way out that way and formed Karup valley with an outlet to Limfjord, passing over dead ice in Venø Bay; when later on Venø Bay was rid of ice, Karup Aa cut its bed deeper down into the outwash plain, thus forming the two terraces along Skive Aa (Karup Aa). A little later, more to the east, saw the forming of the now dried-up "Falborg Valley", which runs almost from Silkeborg northwards along the Gudenaa to Tange, from there westwards, south about Viborg over Viborg Heath and Revn Heath (two wide fluvial plains) to Hjarbæk Fjord, where it emptied over buried dead ice. The function of "Falborg Valley" was taken over direct by Gudenaa - Skalsaa valley, which likewise had its outlet over the ice in Hjarbæk Fjord. When the ice in the fjords east of Salling melted away, Skive Aa made its present outlet to Skive Fjord, the river just south of Skive cutting through its own terrace because the water no longer had any need to run westwards to Venø Bay, but was able to make its way out to the now unblocked Skive Fjord. Some time after these fjords had become icefree the ice at Randers melted away, so that the water from Gudenaa valley was no longer forced over into Skalsaa valley but made its present outlet at Randers. Almost at the same time the ice in the neighbourhood of 
Silkeborg melted away so much that the Gudenaa's upper course was developed. Later on the long fluvial system of the Gudenaa served as an outlet for part of the meltwater from the ice which, at a later advance, formed the "East Jutland stationary line" described by PouL HARDER (1908). To this stationary line correspond some meltwater valleys in Djursland, which now occur as high terraces. At the issue of the meltwater river at Glatved, south of Grenaa, enormous quantities of large boulders were deposited, to a great extent consisting of Saltholm limestone.

All these extramarginal meltwater valleys have been of tremendous significance to the draining of Jutland. On the islands there are also meltwater terraces along some of the largest rivers, for instance Odense Aa and the upper course of the Susaa; in the melting period the Susaa had its outlet through Aamose and Saltbæk Vig to Sejrø Bay. There are small outwash plains on Funen between Odense and Nyborg, and on Sealand south of Arresø; there are also many small areas round about in the country.

Sometimes one also comes across late-glacial lake sand; the best known is the sand around the stoneless clay at the aforementioned Stenstrup lake on Funen.

\section{Late-Glacial Marine Deposits.}

At the close of the last glacial period the northern part of Jutland, Vendsysse1, lay much lower than it does now; at that time it was a group of large and small islands. In the sea between the islands was deposited in fairly deep water the Yoldia Clay, and at the edge of the beach the upper Saxicava Sand, which, gradually as the land raised, spread over greater and greater areas. Saxicava sand now covers large stretches of the Yoldia clay, which, however, always lies well up under the surface and in many places crops out. Where during the maximum of the submergence there was coast, the Saxicava sand lies direct upon the glacial deposits.

For a short period the emergence was interrupted by a new submergence, in which Zirphaea Sand was deposited over a small area.

The late-glacial sea bed now occurs as fairly high plateaux; in Vendsyssel they form a large and very characteristic part of the landscape.

These plateaux lie up to 30 to 34 metres above sea-level in Northeast Vendsyssel, where the emergence after the late-glacial period has been most marked. The highest shore line in the whole of the raised area is to be found south of Frederikshavn, lying 56 metres above sealevel. The height decreases rapidly towards the southwest as far as a 
line from the east of Thy across Djursland; along that line the level may be put at Zero. (Axel Jessen 1918).

Yoldia clay is worked especially in the district round about Nørresundby and Aalborg, where together with the chalk it is used in making cement.

On Bornholm the signature "Late-glacial marine deposits" is employed in perhaps a misleading manner to mark deposits from the Baltic ice-lake. In the late-glacial period the southern part of the Baltic valley was so high in relation to the sea that the two were unconnected, and therefore it contained an ice-lake which had an outlet to the sea along varying routes. For a time the water was dammed so high up that the lower parts of Bornholm were partly covered by the lake. By this means marks were made at a height of 9 to $10 \mathrm{~m}$ above sea-level along the south coast and at a height of 20 to $21 \mathrm{~m}$ at Hammeren. The sediments are beach stones and raised beaches.

\section{Dune Sand.}

The principal region of the occurrence of blown sand in Denmark is the West Coast of Jutland along its entire length. The dunes occur in a belt varying in width up to 10 kilometres, but they are not so pronounced a feature everywhere. The most characteristic dune landscapes in Jutland are north of Limfjord; the Skagens Gren (point) particularly is famous for the great white (unplanted) dune Raabjerg Mile (Studeli Mile) which is allowed to move eastwards without human interference. Otherwise most of the dunes either by human means or by the hand of nature have been planted, so that the movement of the sand is restricted to a minimum. In Han Herrederne between Jammerbugt and Limfjord there are handsomely developed parabolaformed dunes with their opening towards the direction of the wind; they have come about through repeated wind-made breaks in dunes covered with vegetation, so-called grey dunes.

Further inland, too, at long distances from the coast, there are dunes, all with vegetation and dating from ancient times. Many of these socalled inland sands were formed upon the ice-free land just in front of the ice or in the late-glacial period itself. Often they occur on the outwash plains, and sometimes at the beginning of an extramarginal river valley; this is the case, for example, with Vrads Sande, which lies at the beginning of the Storaa Valley about $15 \mathrm{~km}$ south of Silkeborg. Some inland sands have been formed in historic times owing to wind-breaks in the heather covering of the heaths.

On the map, only those inland sands are shown which occur in the 
form of dunes. However, in the interior there is blown sand which has not been deposited in dune form; the geological mapping has shown that blown sand sometimes lies as a perfectly flat covering, which does not make the landscape differ from the surrounding country. The probable explanation of these deposits is that the sand has been bound by the moisture in the low-lying regions and therefore has been unable to sweep into dunes as is usually the case with blown sand. These regions, in which only the soil, but not the landscape, has been marked by the blown sand, are not particularly common, and, as they play no great part as a soil variety either, they are not included in the regions marked as blown sand, but under the same designation as their surroundings, which almost exclusively means diluvial and heath sand.

There are also blown-sand areas on the islands, though they are small. Besides on the sandy islands of Læs $\varnothing$ and Anholt they are to be found on the more clayey islands: at the south point of Erø, at Ristinge on Langeland, along the north coast of Sealand, especially in the region of Tisvilde-Melby Overdrev, and finally the considerable sand deposits at Dueodde and other places on Bornholm.

In the 16th and 17th centuries the sand drift caused great destruction on the west coast of Jutland and, for instance, at Tisvilde and on Bornholm, as well as at other places.

\section{Post-Glacial Marine Deposits.}

In the Stone-Age period Denmark was visited by a transgression of the sea, which made the fjords deeper and caused them to extend further, often very much so, into the country than they do now. This involved a change in the conditions of life of the marine fauna, and, as at the same time a maximum of high temperature set in, the fauna in the fjords became richer. The Stone Age people lived then to a great extent on the products of the sea, and in the first phase of the StoneAge Sea we find their heaps of shells lying along the shores of the former fjords. The sea then is called the Litorina Sea or Tapes Sea.

The marine deposits from that period are to be found in the low regions in the north-easterly parts of the country. The only part of the country that has not been raised up over the level of the Litorina Sea is the south-westerly region, SW of a line from Nissum Fjord to Middelfart and from there across the north point of Langeland to the northern part of Falster.

The greatest emergence is to be found at Frederikshavn, where now the land rises to $13 \mathrm{~m}$ above the Stone Age level. From there the height 
decreases gradually towards the southwest to the line referred to above, where the rise is nul.

Randers Fjord ran almost as far in as to Viborg; post-glacial marine sediments have been found in Nørreaa valley as far in as to Brunshaab, $4 \mathrm{~km}$ SE of Viborg. By this transgression Vendsyssel was also cut up into several islands, though not so much as in the late-glacial period, as the transgression was not nearly so considerable as then. As a consequence, the post-glacial marine deposits lie in a belt outside the lateglacial marine deposits in Vendsyssel. Most of Han Herrederne and the whole of the western part of Thy in the Stone Age lay under water; large parts of the emerged areas are now covered with blown sand, and the stretches marked with the signature for dune sand to a great extent belong to those regions that have been affected by the Litorina submergence. Furthermore, Skagens Gren, and both large and small Vildmose, were submerged. Kolindsund in Djursland extended through the peninsula from the Cattegat to Randers Fjord, and so one might mention innumerable changes from the time of the Stone-Age Sea, for instance in North Sealand too. As regards North Jutland, see AxEL JESSEN (1920); a collective summary of emergences and submergences is given by AxeL Jessen in "Summary of the Geology of Denmark" (1928), and by E. L. Mertz (1924).

The submergence in the Stone Age was not very great, and the sediments from the Stone-Age Sea that now are raised above the sealevel are therefore littoral or shallow-water deposits. For the most part they are raised beaches, and otherwise sandy deposits, more rarely mud.

The commonest post-glacial marine deposits are the usual beach deposits, which in West Jutland especially sometimes occupy large areas. All along the coast of the North Sea is a wide strand belt, mostly with fine beach-sand inside the pebble belt, which lies at the water's edge. The beach sand is blown by the frequent and strong west winds into dunes, which form a more or less wide belt just inside the beach area.

Very often the raised beaches are to be found covering rather large areas with whole systems of almost parallel mounds. They have been produced partly as a consequence of the emergence itself and partly as a natural development of their own tendency to expand, as they protect the already gained areas and constantly spread themselves over new ones.

At places where there are indentations in the coast the currents of the sea will form points and isthmuses which in the end turn the indentations into lakes with only a narrow connection with the sea. Several of the Jutland lakes along the North Sea coast have originated in this manner. 
When the points stretch so far out that they succeed in connecting submarine reefs with the mainland, we often find areas like Skagens Gren, where now the raised beaches form gigantic systems, showing how the currents in the sea have been able to throw so much material up into the mounds that they have formed a very considerable expansion of the land area (Axel Jessen, "Vendsyssels Geologi" 1918).

Along the coasts of Denmark artificial measures have reclaimed large areas which are now cultivated. Many coves, bays and a few fjords have been converted into fertile arable land. The soil varies considerably; in some places it is very sandy, in others clayey and greasy. Although these areas have not been raised above the sea level by nature's own forces (in fact, they lie sometimes several metres below it), they must be included under the post-glacial marine sediments and therefore are put together with these on the map. The reclaimed areas are discussed in greater detail by V. Mnthers (1925) in the section "Danmarks Jord" in "Det danske Landbrugs Historie".

\section{Post-Glacial Freshwater Deposits.}

On the map a distinction has been made between bogs and meadows among the post-glacial deposits. This distinction is not easy to make; in the first place it expresses what alluvial freshwater deposits are utilised for peat-cutting or are suitable for that purpose, and what is utilised in other ways or lies unexploited.

The term bog comprises both eutrophic lowmoor peat series which in particular occur in riverside bogs and spring bogs, and oligotrophic Sphagnum peat series, to which belong the high bogs proper. The signature "meadow" comprises all other alluvial freshwater deposits such as mud, sand and clay, as well as spring and bog lime.

The freshwater deposits are equally distributed all over the country; but, on account of their origin in close association with calcareous water, spring and bog lime do not exist outside of the limits of the last glaciation.

Along the watercourses the signature for bogs or meadows has been added where the valley is so wide that it is technically possible to include it on the map without distortion so that the signature overlaps into other areas. As the valleys often are narrow, so that they would not be visible on a map of this scale, there are sometimes interruptions in the picture of the freshwater deposits along the watercourses. (See also Knud Jessen, 1918 and 1920). 


\section{Marsh.}

Along the southern part of the west coast of Jutland a deposition of greasy marine clay is constantly proceeding, the so-called marsh clay, which is laid down at flood tide as a sediment of the sea water, which leaves the greasy clay hanging on plants and small animals at ebb. The formation of the marsh is constantly being displaced, partly because its own growth causes the surface to lie higher, partly because a continuous emergence after a brief submergence in the time after the Bronze Age is gradually leaving the already formed marsh areas dry; the emergence has been about 1.2 to $1.4 \mathrm{~m}$ since the Bronze Age (Axel Jessen "Marsken ved Ribe" 1916).

\section{Rock Outcrops.}

The term "rock outcrop" will be found only on Bornholm, as it is the only place in Denmark where the outcrop consists of rock in situ.

It is mostly within the granite area that the substratum crops out without the protection of Quartary deposits. One reason is that the granite area, which forms the north-easterly two-thirds of the land, forms the exposed side of the island, whereas the sedimentary deposits from the world's antiquity and middle ages are on its lee side in relation to the flow of the ice.

No distinction is made on the map between different kinds of substrata, as to which reference is made to V. Mutrhers (1930) and, as regards the Archaean, to K. Callisen (1934). 


\section{The Soil of Denmark.}

Whereas Geology is a subject dealing with the rock structure of the globe, it is the particular object of soil science to study that part of the earth's crust in which plants grow. The soil scientist occupies himself with the soils, that is to say, the surface layers of the earth in which great changes have been wrought by the influences of climate and vegetation, and in which the roots of the plants essentially spread.

All vegetation on land, with the exception of rock lichens and mosses, depends directly or indirectly upon a soil in which all higher plants (not counting some parasites and epiphytes) are fixed by means of their roots, and therefore, next after the climate, the soil is the principal determining factor for the vegetation. Whereas the climate draws the broad lines governing the various types of vegetation over the globe, it is the nature of the soil and its humidity which locally determine the variation of the natural vegetation from place to place.

The interaction between soil and vegetation is mutual, however. The fact is, that a very important component of the soil, especially in its uppermost horizon, is humus, an organic substance formed by dead organisms, particularly those of the plants and their fallen leaves. As the dead materials of the various plants differ in the rapidity of their decomposition and give rise to a variety of biological conditions in the ground, the "humus state" depends greately on the vegetation.

In Denmark a distinction is made between two ordinary types of humus: "mull" and "mor"1), and two soil types: brown-soil (sialite) and podsol.

In genuine mull the humus formed by the plant remains is intimately mixed with the mineral soil. The principal process in the formation of this mixture is that the earthworms draw the plant remains down into their burrows and, when they have become tender, devour them. Earthworms also swallow a lot of soil, and their casts, which they eject on the surface

\footnotetext{
1) "Mull" and "Mor" have been adopted as international terms by the International Union af Forest Research Organizations, Nancy 1932, and by the International Society of Soil Science, Oxford 1935.
} 
of the ground, consist of a mixture of humus and mineral soil. Where there are many earthworms the whole surface of the ground will be covered with a layer of such casts, of which actually the entire upper soil layer has been made, and in such places the mull passes insensibly into the mineral soil.

With more superficial work, by smaller species of earthworms, there is a gritty, very humic mull deposited on top of the mineral soil. Here, too, the humus substances are mixed with mineral soil, but not in quantities large enough to be conspicuous.

The feature of the humus type mor is that there is no intermixture of mineral soil, or at any rate only very little. In all cases the mor forms a surface layer that is sharply delimited from the mineral soil. Its origin is due to slow and incomplete decomposition of the organic waste substances, without the assistance of animal organisms such as earthworms to mix humus and mineral soil together. Uppermost, mor consists of a loose layer of leaves, needles, and so on, in a state of active decomposition and more or less broken down ( $\mathbf{F}$-layer $=$ fermentation layer $)$, and underlying it a denser, more or less coalescent and fine-grained humus mass (H-layer = humified layer). It is a kind of peat formation on dry land.

Of the two surface types brown-soil is normally associated with the mull, whereas podsol and mor go together. Under the influence of the carbon dioxide in the percolating rain-water there will be a weathering of the minerals in the ground; and first of all the calcium carbonate will be dissolved. After the Glacial Age calcium carbonate was abundantly contained everywhere in the deposits from the ice which had passed over the Baltic Sea, whereas the northeast parts of Jutland and North Sealand, whose material came from the north, were rather poor in calcium carbonate. This difference is still observable, but there has been this change, that in the course of time the free calcium carbonate where the earth is sandy and easily permeable for water has been washed out to such a considerable depth that it cannot be reached by the roots of the plants, whereas on clayey land calcium carbonate which bubbles in hydrochloric acid is often found at such depths as to be within reach of the plants.

In addition, however, felspars and other more resistant minerals are gradually dissolved, thus releasing various substances: calcium, magnesium, potassium, sodium, iron, aluminium, phosphoric acid, silicic acid and others, several of which are indispensable plant nutrients. These substances will behave differently according to whether the percolating surface water is more or less acid.

Under good mull, which as a rule is only slightly acid or neutral ( $\mathrm{pH}=$ $5-7$ ), the humus substances dissolved by the surface water, in conjunction with the mineral substances are deposited in a thin film round the mineral grains. This gives them a brownish coating from which is derived the name 
brown-soil, also called sialite according to the silicic acid and aluminium content (besides that of iron, humus and bases). The fertility of brownsoil is very greatly dependent upon the ability of this film to absorb moisture and plant nutritives. Calcium carbonate being the principal factor in the reduction of the acidity of the soil, lime has a protective effect on brown-soil and the mull state, which consequently are met with almost wherever calcium carbonate is to be found near to the soil surface.

Where the mull is more acid $(\mathrm{pH}=4-5)$ the ground water can dissolve the aforesaid film, whereby the mineral particles appear without it and have a whitish tinge. This is reflected in a "degrading" of the brown-soil in the form of white sand grains or pale patches in its upper part. At the same time the soil loses something of its aggregate structure and has a tendency towards single-grain structure and closer bedding.

It is only when the earth is covered with mor, however, that the bleaching becomes so strongly developed that we get the type of soil known as podsol. In podsol all mineral particles in the upper soil layer are completely bare of any film, and into the bargain they are weathered on the surface, so they have a dull, whitish lustre; it is called leached sand.

The ingredients dissolved in a leaching horizon (Horizon A) will farther down, in a precipitation horizon (Horizon B), usually be deposited round the mineral particles, which are then enclosed in brownish or blackish films and more or less firmly cemented together. If Horizon B is quite loose and friable, uniformly yellowish, brown or dark-brown, and steadily lighter in colour downwards, it is called soft pan; but if it is patchy, mostly with black veins and black at the top, and more or less compact or hard, it is called pan or hard pan. Presumably soft pan in most cases is a much younger formation than pan.

\section{Common Soil Types.}

Mull-Brown Soil. Natural forms occur in this country under foliferous forests of beech with rich herb flora, light-demanding trees (oak, sycamore, elm, ash, alder) with undergrowth of bushes and herb flora, copses and scrubs, or pastures with grass and herbs. The upper two centimetres of the soil are loose and lumpy, under which it is friable, and the lumpy structure can be followed a good way down in the topsoil, which is brownish or grey-brown and in most cases has a depth of 30 to $60 \mathrm{~cm}$., and passes insensibly into the subsoil which mostly is somewhat weathered and decalcified at the top.

Mull-Degraded Brown Soil. Especially common in beech forests on light soils and in the oak copses in heath land. Rather superficial and acid, dark, often little coherent mull or surface mull. Lump structure 
less prominent or almost absent, so that the topsoil is dense. Distinct bleaching in and just under the mull layer, and often down into the topsoil as well. Also in spruce forests on good bottom.

Slightly Podsolized. Usually a thin or loose, friable mor layer or mor of relatively recent date. The flora is the characteristic one: in the forest: mosses, hair-grass, may-flower, lily of the valley, cow-wheat; on plains young heath vegetation. Under the mor is a layer of leached sand from a few centimetres to 1 or $2 \mathrm{dm}$. thick at the top of the soil, which has no distinct precipitation horizon. Under newly-formed mor it is possible to find a few millimetres to one or two centimetres of leached sand, with an equally thin but quite distinct precipitation horizon. Mostly the soil is dense and poor in humus.

Moderately Podsolized. Common both in forests, especially of beech and conifer, and in heaths. Under a typical mor layer is a welldeveloped leached sand $(10-20 \mathrm{~cm}$.), and under that again soft pan. The podsol profile sometimes occupies the entire topsoil, or there may be a remnant of the original topsoil underlying the soft pan.

Strongly Podsolized. Sharply delimited leached sand over pan, a decided heath-soil type. In the leached sand, which is white or grey, humus is frequently interbedded in the form of a dark layer at the top underlying the mor and at the bottom just over the pan. The pan is usually black at the top, then mixed coffee-brown, brown, and ochre, and gradually lighter brown to yellowish downwards.

Under about $5 \mathrm{~cm} .(2-8 \mathrm{~cm}$.) of mor the ordinary heath podsol has about $25 \mathrm{~cm}$. of leached sand, darkest at top and bottom, and about $25 \mathrm{~cm}$. of variegated pan, most of it very friable, and below this the soil for some distance down is more rust coloured than the subsoil.

Very strongly Podsolized. Often, however, and especially in moist places, the pan is more developed, and to a great extent black and hard. Of remarkable character are the so-called "Altappe", columns of hard, black pan, often with a core of leached sand, extending through the brown pan and down into the rust-coloured sand or right down into the sub-soil, tapering off conically downwards. These columns may be from one or two centimetres to several decimetres in diameter, and frequently the largest of them spread out in the subsoil into large horizontal plates of hard pan. In places there is a layer of black, hard pan from a few centimetres to several decimetres thick, overlying the brown pan. These heavy forms of pan are often found in conjunction with old blown-sand formations, where the leached sand layer has been made very thick by wind-swept sand.

In moist places is often found an advanced development of the so called peaty pan, a relatively soft, humus-rich layer over the black or brown pan.

During these investigations a particular pan-podsol has been met with in the southeast of Denmark on small flat areas, where a sandy soil almost 
as fine as clay (silt) is overlain by ordinary fine sand. A section from Hannenau Forest on the island of Falster had, under the mor layer, $20 \mathrm{~cm}$. of compact, greyish, fine-grained leached sand, $18 \mathrm{~cm}$. of dark, coffee-brown hard-pan (lumps can be crushed with the hand), $7 \mathrm{~cm}$. of dark brown, very hard pan (lumps cannot be crushed and are hard to break with the hand), and then compact, firm, yellow sand up to $90 \mathrm{~cm}$. Under this was silt of clayey character which carried the ground-water; it was blueish in colour from $160 \mathrm{~cm}$. and contained calcium carbonate from a depth of $180 \mathrm{~cm}$.

We may say that the mull-brown soil is characterised by the fact that the humus horizon extends far down into the mineral topsoil, in fact under favourable circumstances right down to its lower boundary, whereas in the mor-podsol soil there is a humus horizon overlying the mineral top-soil and sharply delimited from it.

Locally over calcareous rock, moraine with a high percentage of calcium carbonate, or calcareous tuff, there is sometimes a basic, calcareous surface humus with a very variegated, calciophillous flora. The cause of the type is partly the direct proximity of the lime, partly the ability of the lime to absorb the rain-water, so that when evaporation takes place from the ground surface, the water rises again saturated with calcium carbonate. In this manner the calcium carbonate movement becomes similar to the phenomena in arid climates (Renzina, the black earth of Russia). Under a layer of calcareous humus of worm-cast structure-often more than a decimetre in thickness - there is a thin layer of rust-brown, mineral topsoil over the lime. The type occurs here and there on chalky ground, for instance Møens Klint.

\section{Distribution of Soil Types.}

Before the distribution of the soil types within the boundaries of Denmark can be understood it is necessary to examine the cause of their occurrence.

Intense leaching, which involves the degrading or podsolization of the soil, depends upon an acid humus layer and a downward water movement whereby the dissolved substances can be carried down into the underground. This leaching is counteracted by upward, capillary water movement to balance evaporation from the ground surface and its vegetation, by transportation of bases absorbed by plant roots with the soil moisture and later deposited on the surface together with the plant remains, and by the transportation of earth from deeper strata to the surface by animals, mainly earthworms.

Consequently, the soil formed depends upon climate, the nature of the 
soil, and the vegetation. A cold, wet climate encourages the formation of mor and gives a large surplus of percolating soil-water. The following figures representing annual temperature and annual rainfall show that the heath districts of Jutland for climatic reasons alone are more exposed to podsolization than the islands to the south:

\begin{tabular}{|c|c|}
\hline $\begin{array}{c}\text { Annual } \\
\text { temperature } \\
{ }^{\circ} \mathrm{C} \text {. }\end{array}$ & $\begin{array}{c}\text { Annual } \\
\text { rainfall } \\
\text { mm. }\end{array}$ \\
\hline 6.7 & 700 \\
\hline $\begin{array}{l}.9 \\
.\end{array}$ & 616 \\
\hline
\end{tabular}

Sandy soil is more likely to be leached than clayey soil. Clay retains more of the rainfall, which again evaporates from the surface, than sandy soil, where the quantity of water sinking down will therefore be greater. In addition, the greater weathering and absorption surface of clayey soil counteracts podsolization. The basic effect of the calcium carbonate hinders podsolization; as a rule it is well washed out of sandy soils, whereas our clayey soils often are rich in calcium carbonate to some depth.

The formation of mor is governed by the nature of the vegetation, but is also promoted by a cold climate and an absence of bases. Vegetation that is particularly favourable to mor-formation includes heather, Pinus sylvestris with a ground flora of blueberries and cowberries, Picea abies, and to a smaller extent beech-forest. As mor may generally be considered to be a pre-condition of podsolization, the state of the soil is dependent on the vegetation not merely of today but of the past as well, right back to the termination of the Glacial Age. Vegetation is not governed by climate and soil alone, but by history too. Over wide areas the destruction of the forests by man and domestic animals has been the cause of the heaths, whereby it has promoted the podsolization of the soil.

Podsolization has developed after the Glacial Age laid down its deposits, but it is very difficult to judge of the age of the podsol. It has been suggested that the podsol of the heaths is traceable right back to a tundra contemporaneous with the waning of the last inland-ice (P. E. MüLLER). This is contested by the fact that in all probability the mean annual temperature in the waning period has been above $0^{\circ} \mathrm{C}$., so that the soil has not been frozen right down, and the characteristic circulatory movement of the earth strata which is thought to have taken place on the "hill-islands" is untraceable on the heath plains, whose sand deposits lie in undisturbed horizontal bedding, just as they were deposited by the meltwater. Furthermore, the heath-sand just after deposition must have contained quite a quantity of calcium carbonate; remains of decalcified bryozoan limestone in the form of soft siliceous nodules are widely distributed and often in fairly large quantities in the heath-sand, and such a lime content, 
Map showing the main distribution of podsol in Denmark.

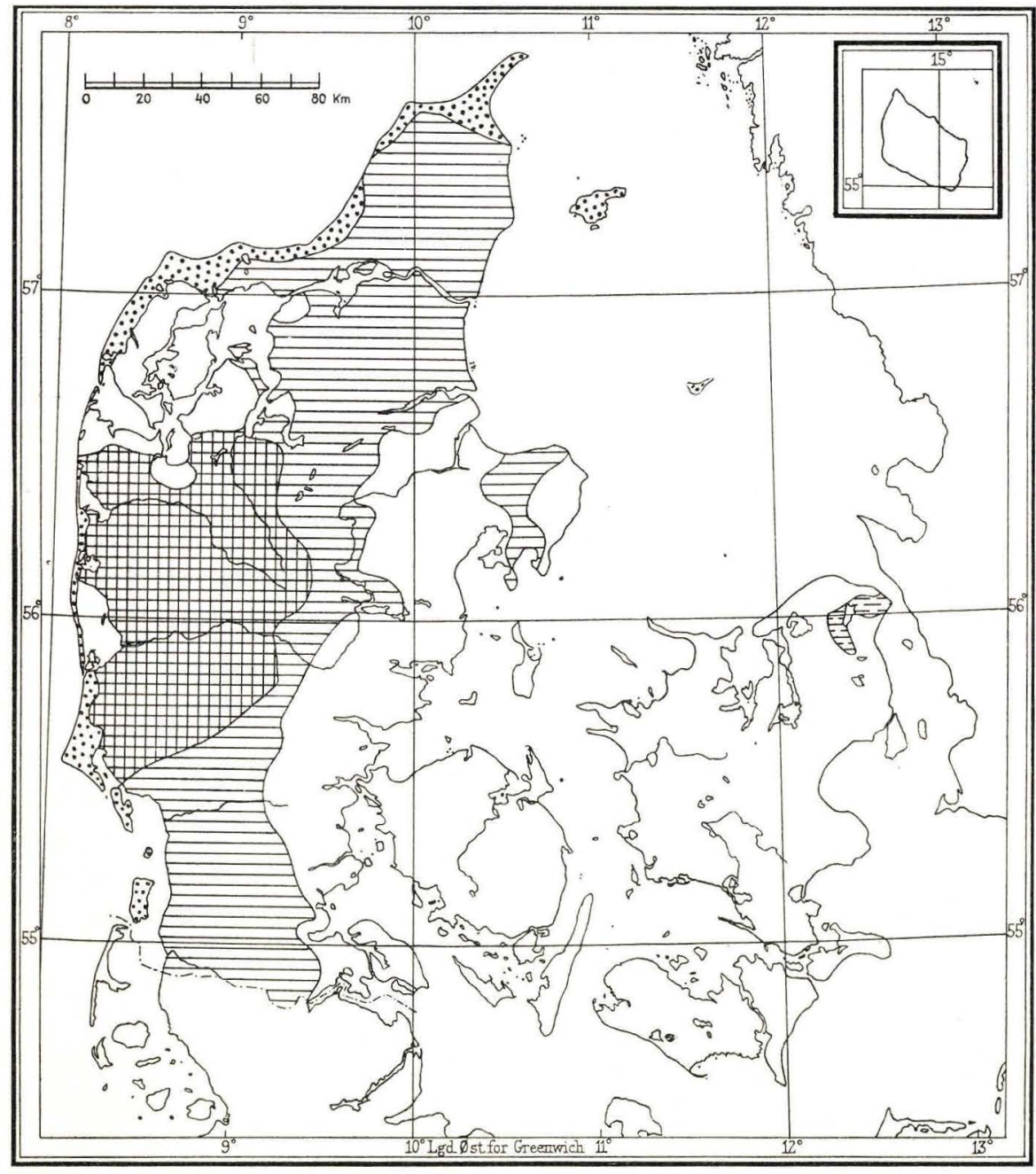

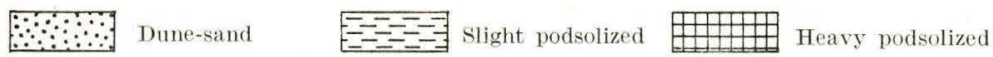
Brown soil $\rightleftharpoons$ Medium podsolized 
which would scarcely be completely dissolved before a higher temperature set in, must have counteracted the formation of mor and podsol.

Indeed, it is not impossible that large parts of the outwash plains always have had a kind of heath flora, into which aspen, birch and later Pinus sylvestris must presumably have intruded; pollen analyses show, however, that heather was no important element in the flora until the cold and wet Iron Age. The heath podsol sometimes dates farther back than the Bronze Age right back into the Stone Age, as is evidenced by finding podsol sections under the tumuli. In all probability the lighter podsols on the heaths in the woodlands have mostly only been formed after the destruction of the forests.

The uppermost soil forming the leached sand layer of the heaths is stoneless to a great extent and of fairly uniform thickness, between 20 and $30 \mathrm{~cm}$. This indicates that the stones have sunk down, a process similar to that which takes place at the bottom of the mull with the help of the earthworms. One might most readily imagine an original mull with earthworm fauna, but perhaps also ants, fossorial wasps and other digging animals that thrive on Calluna heaths.

The distribution into West Jutland hill-islands, extra-marginal sand plains, diluvial sand and clayey soils, combined with the humid climate of West Jutland, has the effect that two main soil-boundaries can be drawn through Jutland, one of which coincides with the Main Stationary Line of the last inland ice along its northern and middle stretches. This boundaries and the distribution of the soil types in broad lines can be seen in the map on page 59 .

The land in front of the ice margin is mostly podsolized to a heavy degree. This is especially true of the outwash plains, whereas large parts of the hill-islands and the slopes of the erosion valleys are only moderately podsolized. The soil condition becomes milder southwards and heavy podsolization is less prominent in South Jutland than more to the north, for example at Karup outwash plain. Especially heavy podsolization is met with sometimes on old sanddrift areas, whereas the extensive dune-sand areas along the North Sea are so young on the whole that podsolization is only little advanced and often only faintly or scarcely visible. Pronounced brown-soil profiles may be found on the clayey parts of the hill-islands.

The middle stretch of Jutland, which is a sandy and mostly very hilly landscape, in the main comprises medium to slightly podsolized soils in those places where there is natural vegetation in the form of forest and heath. Northwards this belt embraces Jutland East of the clayey, calcareous soils round the western part of the Limfjord, out to the Cattegat almost down to Randers Fjord. There the podsol area bends awayfrom the coast, and farther south East Jutland together with the Danish islands forms a large continuous brown-soil area, in which, however, there are 
several podsol patches larger or smaller in extent. In South Jutland the medium podsolized area runs out to the marshes, but is in several places interrupted by parties with heavy podsolization. In the Central Jutland podsol area the heaths, which for the most part have once been forests, are characterised by medium podsolisation with a soft-pan horizon; only where there are sandy plains in river valleys and in front of later icemarginal lines or old inland drift-sands, do we find strong podsolization. In the forests medium to slight podsolization is general, but large wooded areas have a mully ground with brown-soil, which, however, for the most part is distinctly degraded. The same applies to the oak-scrubs in both Middle and West Jutland, where the soil in most cases is very degraded and therefore readily turns into podsol when the scrubs are destroyed and become heath.

A fairly large, isolated, medium podsolized area occurs in Djursland, whereas corresponding sandy areas on the islands can scarcely be so designated, for although medium podsolization does occur, the main type is slight podsolization and degraded brown-soil. The reason may be that pronounced Calluna heaths are not general, the podsol occurring mainly in beech-woods and on commons, where there is heather, certainly, but perhaps on account of the milder climate it is not so predominating in the flora and eapable of forming mor as on the Jutland heaths. Among the extensive degraded to slightly podsolized areas on the islands there are the regions round Lake Esrom, parts of the so-called "Funen Alps", the sandy country stretching over Bromme Wood out towards Saltbæk Cove, and the Mogenstrup Ås area.

Podsol is to be found locally, within small areas, in many places. Slight to medium podsolization is common in the beech-forests on sandy or slightly clayey, non-calcareous soil, especially where the ground has been covered with mor owing to its having been exposed to wind.

The aforementioned very hard pan on fine sand over silt has been met with at Ullerup in Funen, in Knudskov in South Sealand, at Hannenau in Falster, and Fyrvænget in Laaland.

Apart from these areas, the islands and East Jutland form one large, continuous brown-soil region, though degradation, at any rate in beech and spruce woods, is a frequent phenomenon. A separate, isolated brownsoil area occurs on the calcareous clayey soils round the western part of Limfjord. Bornholm, too, is mostly brown-soil; on the large heather-clad areas in the interior of the island podsol may be found, but - presumably owing to the special character of the moraine - the degree of podsolization is only slight to medium.

Changes in the character of the soil may be brought about by cultural interference. Mull can be changed to mor, and vice versa, solely by the alteration which in forest cultivation takes place with the local climate 
and with the plant varieties in plantation and undergrowth. Where there is mor on brown-soil and mull over podsol, it may be assumed that the topsoil type is due to another humus type than the present one. This divergence between humus and top-soil type is common, for instance, in the beech stands of Gribskov. One can also find oak scrubs with mull flora over podsol, indicating that the area has been heather-grown, at any rate for a time.

Agriculture changes the soil much more radically. Through tilling, the addition of marl and manure, and the introduction of a new covering of vegetation, podsolized heath gradually assumes the character of brownsoil, even if the leached sand can often be distinguished in the fields for many years. The change proceeds more quickly under deep ploughing and pulverisation, during which the colloids precipitated in the pan are brought up to the ploughing depth, and the distribution of the colloids that characterizes brown-soil is at once roughly re-established mechanically. Where the soil treatment has not got right down, the original soil type will often be recognisable for a very long time. Whereas a restoration of the mull condition will often be possible within a few years simply by improvements in the local climate and a change in the vegetation, a transformation of podsol to brown-soil, if at all feasible without deep tilling, requires centuries. 


\section{Kortets Udarbejdelse.}

Til Jordbundskortets Udarbejdelse er følgende Kilder benyttet: Beskrivelserne til de geologiske Kortblade, udgivet af Danmarks GeoloGiske Undersøgelse I. Række Nr. 1-16:

Nr. I. K. Rørdam. Kortbladene Helsingør og Hillerød. 1893.

2. N. V. Ussing og Victor Madsen. Kortbladet Hindsholm. 1897.

3. Axel Jessen. Kortbladene Skagen, Hirtshals, Frederikshavn, Hjørring og Løkken. 1899.

4. Axel Jessen. Kortbladene Læesø og Anholt. 1897.

5. Victor Madsen. Kortbladet Samsø. 1897.

6. K. Rordam. Kortbladene Kjøbenhavn og Roskilde. 1899.

7. Victor Madsen. Kortbladet Bogense. 1900.

8. K. Rørdam og V. Milthers. Kortbladene Sejrø, Nykjøbing, Kalundborg og Holbæk. 1900.

9. Victor Madsen. Kortbladet Nyborg. 1902.

- 10. Axel Jessen. Kortbladene Aalborg og Nibe (nordlige Del). 1905 .

- 11. V. Milthers. Kortbladene Faxe og Stevns Klint. 1908.

- 12. Axel Jessen. Kortbladet Skamlingsbanke. 1907.

- 13. K. A. Grönwall og V. Milthers. Kortbladet Bornholm. 1916.

- 14. Axel Jessen. Kortbladet Varde. 1922.

- 15. V. Mrlthers. Kortbladet Brkke. 1925.

- 16. Axel Jessex. Kortbladet Blaavandshuk. 1925.

Af Danmarks Geologiske Undersogelse III. Række:

Nr. 10. V. Milthers og Th. Claudi Westh. Viborg Egnens Mergellag og deres geologiske Omgivelser. 1913.

- 11. V. Mitthers. Mergel og Kalk i det nordvestlige Jylland. 1914.

- 13. - Mergelaflejringerne i Hammerum Herred. 1916.

- $15 . \quad$ - Mergelen i Holstebro Egnen. 1917.

- 19. _ Jordbundsforholdene omkring Overlund ved Viborg. 1920.

- 23. ㄴ Kalk og Mergel paa Sjælland. 1923. 
Axel Jessen. 1920: Stenalderhavets Udbredelse i det nordlige Jylland. D. G. U. II. Række Nr. 35.

Poul Harder. 1908: En østjydsk Israndslinje. D. G. U. II. Række Nr. 19.

N. V. Ussing. 1903: Om Jyllands Hedesletter og Teorierne for deres Dannelse. Videnskabernes Selskabs Oversigter.

N. V. Ussing. 1907: Om Floddale og Randmoræner i Jylland. Videnskabernes Selskabs Oversigter.

Danmarks Geologiske Undersøgelses Arbejdskort fra følgende geologiske Kortblade under Udarbejdelse: Ribe, Tønder, Brande, Vamdrup, Fredericia, Haderslev, Sønderborg, Vissenbjerg, Faaborg, Svendborg, Gulstav, Korsør, Sorø.

Hedeselskabets Arbejdskort over Tørvemoserne i følgende Amter: Thisted, Ringkøbing, Viborg, Aalborg, Randers, Aarhus og Vejle.

Danmarks Geologiske Undersøgelses Mergelarkiv.

Et ikke udgivet Jordbundskort over Danmark 1:320 000 af Professor C. F. A. Tuxen.

Følgende Konsulenter har elskværdigst meddelt Oplysninger om Forholdene i deres Landboforenings Omraade:

A. KorsgandD: Nordthy.

J. M. Christensen: Det thylandske landøkonomiske Selskab.

N. MølgaARD: Skodborg-Vandfuld Herreder.

A. SkarregaARD: Ulfborg-Hind Herreder.

C. VADGaARD: Bølling-Nørre Herreder.

N. Svaneborg: Han Herreder.

Andr. SøndergaArd: Morsø Husmandskreds.

J. Lund: Salling.

P. O. OvergaARD: Hjerm-Ginding Herreder.

N. Offersen sen.: Vinding-Vind-Nr. Omme.

A. Binderup: Hammerum Herred.

N. J. Vester: Vesthimmerland $\mathrm{m}$. fl.

A. V. Pedersen-Aidt: Viborg Amts landøkonomiske Selskab.

F. Mortensen: Kellerup og Omegn.

N. P. Johansen: Bjerringbro og Omegn.

J. C. Andersen Lyngvad: Aalborg Amt.

S. A. Rasmussen: Den nordvestl. Del af Randers Amt.

Th. Jensen: Randers Amts Landhusholdningsselskab.

J. Jacobsen: De fire midtjydske Landboforeninger.

G. Georg Hansen: Høver og Omegn.

Chr. Pedersen: Tyrsting-Vrads Herreder.

J. E. Jensen: Skanderborg. 
C. P. Müller: Tørring og Omegn.

M. C. Jorgensen: Horsens Landbrugsforening.

Johs. Nyноцм: Rougsø Sønderhald Herreder.

E. Mouritsen: Aarhus Amts landøkonomiske Selskab.

N. Primdahl: Hads Herred.

J. C. Ellehauge: Kalø Vig.

A. Larsen Ledet: Djursland.

M. Olsen: Sorø Amts landøkonomiske Selskab, Slagelse og Omegn.

H. P. Hansen: Skelskøregnen.

Geert Olsen: Sorøegnen.

O. Pinholt: Ringstedegnen.

M. BAKMAN: Sydsjælland.

H. H. Holme Hansen: Laaland-Falster.

A. P. Andersen: Nr. Rangstrup.

Samt for Sønderjyllands Vedkommende: Kreditforeningsdirektør Haxs HaNSEN.

I de Omraader, hvor Danmarks Geologiske Undersogelse endnu ikke har foretaget den detaillerede geologiske Kortlægning, har jeg undersøgt Jordbundsforholdene ved Oversigtsrejser i Aarene 1929, 1930 og 1932.

Paa dette Grundlag har jeg udarbejdet Jordbundskortet i Maalestok 1: 160000 , som derefter er omsat til det foreliggende Jordbundskort over Danmark i Maalestok 1: 500000 .

Keld MiLthers.

Som Grundlag for Oversigten over Overgrundstypernes Fordeling er ganske overvejende benyttet Materiale, som er indsamlet med dette Kort for Øje i Løbet af Aarene 1928 og 1929. Antallet af Undersøgelser har derfor kun kunnet blive meget begrænset, ialt kun c. 800 Profilbeskrivelser, og man har som Følge heraf ikke saaledes som for de geologiske Forhold kunnet give en detailleret Kortlægning af de forskellige Formers Udbredelse. Man har i Stedet valgt at indlægge alle Enkeltundersøgelserne paa Kortet med Signaturer, som angiver de forskellige Podsoltyper og den stærkt degraderede Bund. Brunjordsprofiler er derimod ikke indlagt, da man af Besparelseshensyn ikke har undersøgt de store Brunjordsomraader uden paa Steder, hvor man kunde tænke sig, at der var Mulighed for at finde Podsolering.

Man har altsaa ikke kunnet aflægge de forskellige Podsolomraader ved Hjælp af tilstrækkelig mange Stikprøver til dermed at kunne fastslaa Grænserne. Et temmelig nøje Billede af Podsoltypernes Udbredelses- 
grænser faar man dog, naar man gør sig det Sammenhæng klart, som der er imellem Jordbundstilstanden og det geologiske Overlag, og som Kortet tydeligt viser.

De lerede Jorder vil praktisk taget alle høre til Brunjorden. Paa alle større Sandpartier vil man, forsaavidt der fandtes Rester af naturlige Jordbundsforhold, finde et Antal Profilundersøgelser, der viser Overgrundstypen, og som i store Træk gælder for de omliggende Dele af vedkommende Sandomraade.

Undersøgelsen er sket paa den Maade, at man med Støtte af Geodætisk Instituts Kortbøger i 1:160000 har opsøgt Steder, hvor den naturlige Jordbundstilstand maatte ventes at være uforstyrret, hvilket især var Heder, Krat, Skove og Overdrev, medens man har undgaaet dyrket Jord. Paa disse Steder er der gravet Jordbundshuller ned igennem Overgrunden og optaget en fuldstændig Profilbeskrivelse for hvert Sted. Dette Arbejde er tilrettelagt af C. H. Bonnebusch, som under Samarbejde paa Rejser rundt i Landet har indøvet de tre Forstkandidater, der har udført Detailarbejdet, saaledes at Beskrivelserne i Marken har kunnet blive ensartet udført. Hertil er føjet en Del tidligere af det forstlige Forsøgsvæsen (Bornebusch) i andet Øjemed optagne Profiler. Efter Kortbogen og de optagne Beskrivelser er Profilerne derefter indtegnet med Signaturer paa det af K. Mıthers tegnede Kort i Maalestok 1:160 000.

C. H. Bornebusch.

\section{Litteraturfortegnelse.}

Johs. Andersen. 1928: Se Victor Madsen. 1928.

Karen Callisen. 1934: Das Grundgebirge von Bornholm. D. G. U. II. Række Nr. 50 .

Karl GRIPP. 1929: Glaciologische und geologische Ergebnisse der Hamburgischen Spitzbergen-Expedition 1927. Abh. Naturw. Ver. Hamburg. Band 22. 2.-4. Heft.

Sigurd Hansen. 1933: De glaciale Aarsvarv i Skåne. Geol. För. Förh. Stockholm. Bd. 55. H. 4. S. $623-643$.

Poul Harder. 1908: En østjydsk Israndslinje. D. G. U. II. Række Nr. 19. Axel Jessen. 1916: Marsken ved Ribe. D. G. U. II. Række Nr. 27. 1918: Vendsyssels Geologi. D. G. U. V. Række Nr. 2. 1920: Stenalderhavets Udbredelse i det nordlige Jylland. D. G. U. II. Række Nr. 35.

1922: Beskrivelse til det geologiske Kortblad Varde. D. G. U. I. Række Nr. 14. 
Axel Jessen. 1928: Se Victor Madsen. 1928.

Kvud J Jassen. 1918: Om Moserne og det postglaciale Klima. »Naturens Verden«.

1920: Moseundersøgelser i det nordøstlige Sjælland. D. G. U. II. Række Nr. 34.

Victor Madsen. 1903: Om den glaciale, isdæmmede Sø ved Stenstrup paa Fyn. D. G. U. II. Række Nr. 14.

1921 : Terrainformerne paa Skovbjerg Bakkeø. D. G. U. IV. Række Bd. 1. Nr. 12.

Victor Madsen m. fl. 1928: Oversigt over Danmarks Geologi. D. G. U. V. Række Nr. 4.

E. L. Mertz. 1924: De sen-og postglaciale Niveauforandringer i Danmark. D. G. U. II Rrkke Nr. 41.

Ketd Minthers. 1935: Landskabets Udformning mellem Alheden og Limfjorden. D. G. U. II. Række Nr. 56.

V. Milthers. 1922: (2. Udg. 1935). Nordøstsjællands Geologi. D. G. U. V. Række Nr. 3.

1925: Danmarks Jord. »Det danske Landbrugs Historie«. 1930: Bornholms Geologi. V. Række Nr. 1. 2. Udg.

1931: Israndens Tilbagerykning fra Ostjylland til Sjælland-Fyn. Medd. Dansk Geol. Foren. Bd. 8. H. 1.

V. Nordmann. 1922: Nye Iagttagelser over den glaciale, isdæmmede Sø ved Stenstrup paa Fyn. D. G. U. IV. Række Bd. 1, Nr. 17.

J. P. J. Rava. 1922: Geologisk Kort over Danmark. D. G. U. III. Række Nr. 22.

A. Rosenkrantz. 1933: Kortfattet Oversigt over Danmarks Geologi. I. A. Uddex. 1914: Mechanical composition of clastic sediments. Bull. geol. Soc. America. Vol. 25. S. 655-744.

N. V. Ussing. 1903: Jyllands Hedesletter. Vid. Selsk. Overs.

1904: Danmarks Geologi. D. G. U. III. Række Nr. 2.

1907: Om Floddale og Randmoræener i Jylland. Vid. Selsk. Overs.

1913: Danmarks Geologi. 3. Udg. ved Povl Harder. D. G. U. III. Række Nr. 2.

BoAs, J. E. V. 1882 : Regnormene, deres Liv og Virksomhed (i : Skildringer af Naturvidenskaberne for Alle, Kbhvn. S. 1029-50).

Bornebusch, C. H. 1931: Dybtgaaende Jordbundsundersøgelser (Det forstlige Forsøgsvæesen XIII).

Dalgas, E. M. 1916: Geographiske Billeder fra Heden, Kbhvn. 1867 68. ny Udg. 
GutnkA, K. 1914: Die Typen der Bodenbildung, Berlin.

Jessen, K. 1920: Moseundersøgelser i det nordøstlige Sjælland (Danmarks geologiske Undersøgelse, 2. R. Nr. 34).

1935: The composition of the forest in northern Europe in epipalaeolithic time (Vid. Selsk. Biol. Medd. XII,1).

Jonassen, H. 1935: Et Pollendiagram fra Karupfladen (Bot.T. Bd.43,3). MüLler, P. E. 1879: Studier over Skovjord, som Bidrag til Skovdyrkningens Theori, I. Om Bøgemuld og Bøgemor paa Sand og Ler (Tidsskr. f. Skovbrug 3);

1884: Studier over Skovjord. II. Om Muld og Mor i Egeskove og paa Heder (sst. 7).

1918: Fortsatte Iagttagelser over Muld og Mor i Egeskove og paa Heder (Dansk Skovforenings Tidsskr. 3).

1924: Bidrag til de jydske Hedesletters Naturhistorie. Karup Hedeslette og beslægtede Dannelser. En pedologisk Undersøgelse (Vid. Selsk. Biol. Medd. IV, 2).

Sarauw, Georg F. L. 1898: Lyngheden i Oldtiden. Tagttagelser fra Gravhøje (Aarb. f. nord. Oldk., II, 13).

Schiødте, J. C. 1876: Insekterne og Mulddannelsen (Tidsskr. f. Skovbrug 1).

Tuxen, C. F. A. 1876: Nogle Analyser af jydsk Hedejord (sst.).

1879: Nogle kemiske Undersøgelser af Jordbunden i Bøgeskove (sst. 3).

1882: Regnormenes Virksomhed ved Mulddannelsen (Tidsskr. f. Landøkonomi).

1884: Nogle kemiske og fysiske Undersøgelser af Jordbunden i Skove og Heder (Tidsskr. f. Skovbrug 7).

WeIs, Fr. 1929: Fysiske og kemiske Undersøgelser over danske Hedejorder (Vid. Selsk. Biol. Medd. VII, 9). 


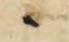

